Prepared for the U.S. Department of Energy under Contract DE-AC05-76RL01830

\title{
Task 3.3: Warm Syngas Cleanup and Catalytic Processes for Syngas Conversion to Fuels
}

\section{Subtask 3: Advanced Syngas Conversion to Fuels}

VM Lebarbier Dagle

$\mathrm{J} \mathrm{Li}$

CE Taylor

Y Wang

March 2014
RA Dagle

C Deshmane

X Bao

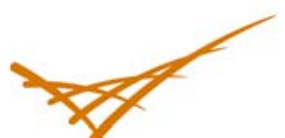

Pacific Northwest

NATIONAL LABORATORY

Proudly Operated by Battelle Since 1965 


\title{
DISCLAIMER
}

This report was prepared as an account of work sponsored by an agency of the United States Government. Neither the United States Government nor any agency thereof, nor Battelle Memorial Institute, nor any of their employees, makes any warranty, express or implied, or assumes any legal liability or responsibility for the accuracy, completeness, or usefulness of any information, apparatus, product, or process disclosed, or represents that its use would not infringe privately owned rights. Reference herein to any specific commercial product, process, or service by trade name, trademark, manufacturer, or otherwise does not necessarily constitute or imply its endorsement, recommendation, or favoring by the United States Government or any agency thereof, or Battelle Memorial Institute. The views and opinions of authors expressed herein do not necessarily state or reflect those of the United States Government or any agency thereof.

\author{
PACIFIC NORTHWEST NATIONAL LABORATORY \\ operated by \\ BATTELLE \\ for the \\ UNITED STATES DEPARTMENT OF ENERGY \\ under Contract DE-AC05-76RL01830
}

Printed in the United States of America
Available to DOE and DOE contractors from the Office of Scientific and Technical Information, P.O. Box 62, Oak Ridge, TN 37831-0062; ph: (865) 576-8401 fax: $(865) 576-5728$
email: reports@adonis.osti.gov

\author{
Available to the public from the National Technical Information Service, \\ U.S. Department of Commerce, 5285 Port Royal Rd., Springfield, VA 22161 \\ ph: (800) 553-6847 \\ fax: $(703) 605-6900$ \\ email: orders@ntis.fedworld.gov \\ online ordering: http://www.ntis.gov/ordering.htm
}




\title{
Task 3.3: Warm Syngas Cleanup and Catalytic Processes for Syngas Conversion to Fuels
}

\section{Subtask 3: Advanced Syngas Conversion to Fuels}

\author{
VM Lebarbier Dagle ${ }^{1}$ \\ $\mathrm{J} \mathrm{Li}{ }^{2}$ \\ CE Taylor ${ }^{3}$ \\ Y Wang Wa $^{1,4}$ \\ RA Dagle ${ }^{1}$ \\ C Deshmane ${ }^{1}$ \\ $\times \mathrm{Bao}^{2}$
}

February 2014

Prepared for

the U.S. Department of Energy

under Contract DE-AC05-76RL01830

Pacific Northwest National Laboratory

Richland, Washington 99352

\footnotetext{
${ }^{1}$ Pacific Northwest National Laboratory

${ }^{2}$ Dalian Institute of Chemical Physics

${ }^{3}$ National Energy Technology Laboratory

${ }^{4}$ Voiland School of Chemical Engineering, Washington State University
} 


\section{Acronyms/Abbreviations}

$\begin{array}{ll}\text { CAS } & \text { Chinese Academy of Sciences } \\ \text { DME } & \text { dimethyl ether } \\ \text { DOE } & \text { U.S. Department of Energy } \\ \text { GHSV } & \text { gas hourly space velocity } \\ \text { HAS } & \text { higher alcohol synthesis } \\ \text { NETL } & \text { National Energy Technology Laboratory } \\ \text { PNNL } & \text { Pacific Northwest National Laboratory } \\ \text { SNG } & \text { synthetic natural gas } \\ \text { syngas } & \text { synthesis gas } \\ \text { TEM } & \text { transmission electron microscopy } \\ \text { TOS } & \text { time on-stream } \\ \text { WGS } & \text { water-gas shift (reaction) } \\ \text { XRD } & \text { X-ray diffraction }\end{array}$




\section{Contents}

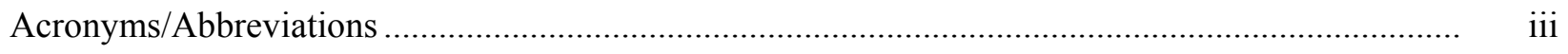

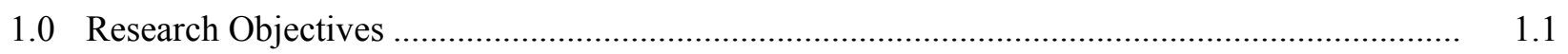

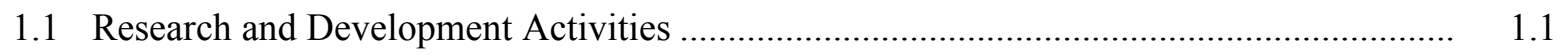

1.1.1 Sorption-Enhanced Synthetic Natural Gas Production from Syngas ....................... 1.1

1.1.2 Syngas-to-Hydrocarbon Fuels through Higher Alcohol Intermediates .................... 1.14

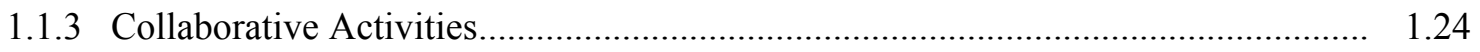

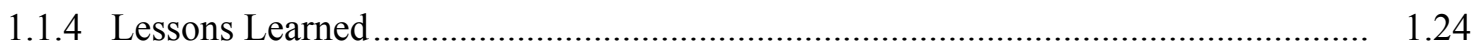

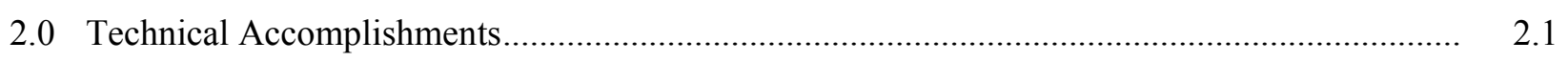

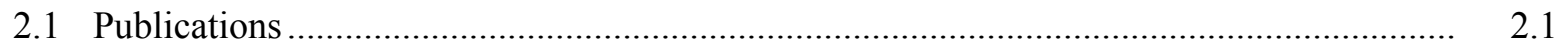

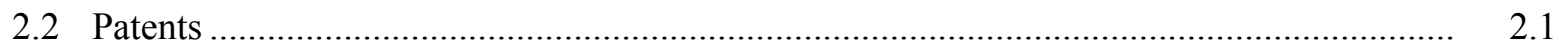

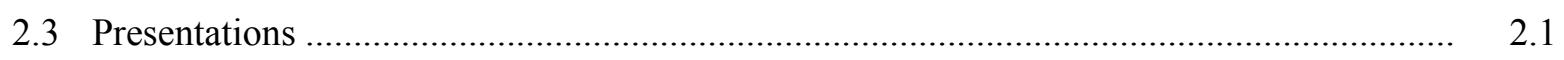

2.4 Demonstrated Technical Results ............................................................................ 2.1

2.4.1 Sorption-Enhanced Synthetic Natural Gas Production from Syngas ...................... 2.1

2.4.2 Syngas-to-Hydrocarbon Fuels through Higher Alcohol Intermediates .................... 2.2

3.0 Recommended Next Steps, Collaborative Work ................................................................... 3.1

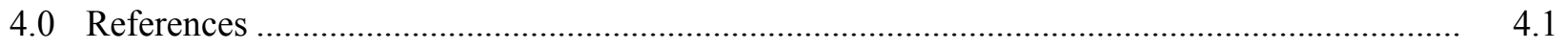




\section{Figures}

1.1 Equilibrium $\mathrm{CO}$ Conversion, $\mathrm{CH}_{4}$ Selectivity, and $\mathrm{CO}_{2}$ Selectivity as a Function of Temperature, Calculated either in the Absence or Presence of Sorbent $(\mathrm{P}=1 \mathrm{~atm}$, molar composition: $\mathrm{H}_{2}=48 \%, \mathrm{CO}=48 \%, \mathrm{~N}_{2}=4 \%$ )

1.2 Evolution of the $\mathrm{CO}_{2} \mathrm{Mol} \%$ Detected from Micro-Gas Chromatography Analysis as a Function of the Carbonation Time.

1.3 XRD Patterns Recorded for the $68 \% \mathrm{CaO} / \mathrm{MgAl}_{2} \mathrm{O}_{4}$ Sorbent before any CarbonationDecarbonation Cycle Labeled as "Fresh," after Carbonation for the First Cycle, and after Decarbonation for Each Cycle.

1.4 Integrated Sorption-Reaction Demonstration.....

1.5 Methane Yield Comparison with and without $\mathrm{CO}_{2}$ Sorption

1.6 CO Conversion as a Function of the Time-On-Stream for the First Two Cycles using the $20 \% \mathrm{Ni} / \mathrm{SiC}$ Catalyst and $68 \% \mathrm{CaO} / \mathrm{MgAl}_{2} \mathrm{O}_{4}$ Sorbent

1.7 TEM Images for (A) the Spent $20 \% \mathrm{Ni} / \mathrm{Al} 2 \mathrm{O} 3$, (B) $20 \% \mathrm{Ni} / \mathrm{MgAl}_{2} \mathrm{O}_{4}$, and (C) $20 \% \mathrm{Ni} / \mathrm{SiC} \ldots$.

1.8 CO Conversion, $\mathrm{CH} 4$, and $\mathrm{CO} 2$ Selectivities for Each Carbonation/Decarbonation Cycle for the $20 \% \mathrm{Ni} / \mathrm{Al} 2 \mathrm{O} 3$ Catalyst and $68 \% \mathrm{CaO} / \mathrm{MgAl}_{2} \mathrm{O}_{4}$ Sorbent

1.9 CO Conversion, $\mathrm{CH} 4$, and $\mathrm{CO} 2$ Selectivities for each Carbonation/Decarbonation Cycle, for the $20 \% \mathrm{Ni} / \mathrm{MgAl}_{2} \mathrm{O}_{4}$ Catalyst and $68 \% \mathrm{CaO} / \mathrm{MgAl}_{2} \mathrm{O}_{4}$ Sorbent

1.10 CO Conversion as a Function of the Time-On-Stream for CO Methanation Reaction for the $20 \% \mathrm{Ni} / \mathrm{SiC}(\triangle), 20 \% \mathrm{Ni} / \mathrm{Al}_{2} \mathrm{O}_{3}(\mathbf{m})$ and $20 \% \mathrm{Ni} / \mathrm{MgAl}_{2} \mathrm{O}_{4}(\square)$ Catalysts (no sorbent) with $\mathrm{T}=500^{\circ} \mathrm{C}$, GHSV $=87000 \mathrm{~h}-1, \mathrm{H}_{2}=48 \%, \mathrm{CO}=48 \%$ and $\mathrm{N}_{2}=4 \%$. Catalyst $=0.1 \mathrm{~g}$ and $\mathrm{SiC}$ diluent $=3.0 \mathrm{~g}$

1.11 XRD Patterns Recorded for the $20 \% \mathrm{Ni} / \mathrm{SiC}, 20 \% \mathrm{Ni} / \mathrm{Al}_{2} \mathrm{O}_{3}$ and $20 \% \mathrm{Ni} / \mathrm{MgAl}_{2} \mathrm{O}_{4}$ Catalysts after Reduction at $600^{\circ} \mathrm{C}$ for $2 \mathrm{hr}$ under $10 \% \mathrm{H}_{2} / \mathrm{N}_{2}$

1.12 XRD Patterns Recorded for the Spent $20 \% \mathrm{Ni} / \mathrm{SiC}, 20 \% \mathrm{Ni} / \mathrm{Al}_{2} \mathrm{O}_{3}$ and $20 \% \mathrm{Ni} / \mathrm{MgAl}_{2} \mathrm{O}_{4}$ Catalysts after the Stability Test for CO Methanation

1.13 XRD Patterns of the Reduced $20 \% \mathrm{Ni} / \mathrm{SiC}$ Catalyst and the Spent $20 \% \mathrm{Ni} / \mathrm{SiC}$ Sample after Two Carbonation/Decarbonation Cycles

1.14 XRD Patterns of for the Reduced $20 \% \mathrm{Ni} / \mathrm{Al}_{2} \mathrm{O}_{3}$ and $20 \% \mathrm{Ni} / \mathrm{MgAl}_{2} \mathrm{O}_{4}$ Catalysts and for the Spent $20 \% \mathrm{Ni} / \mathrm{Al}_{2} \mathrm{O}_{3}$ and $20 \% \mathrm{Ni} / \mathrm{MgAl}_{2} \mathrm{O}_{4}$ Samples after Multiple

Carbonation/Decarbonation Cycles.

1.15 CO Conversion as a Function of TOS for the HZSM-5+0.5Pd/FeCuCo Mixture; $\mathrm{H}_{2} / \mathrm{CO}=1, \mathrm{~T}=300^{\circ} \mathrm{C}, \mathrm{P}=70$ bars, GHSV $=3000 \mathrm{hr}^{-1}, \mathrm{HZSM}-5 / 0.5 \mathrm{Pd} / \mathrm{FeCuCo}$ ratio is 3:1 by Weight

1.16 CO Conversion and Selectivities as a Function of the Temperature for the HZSM$5+0.5 \mathrm{Pd} / \mathrm{FeCuCo}$ Mixture; $\mathrm{H}_{2} / \mathrm{CO}=1, \mathrm{P}=70$ bars, GHSV $=3000 \mathrm{hr}-1$, HZSM$5 / 0.5 \mathrm{Pd} / \mathrm{FeCoCu}$ ratio $=3: 1$ by weight.

1.17 Alcohol Product Distribution for Conversion of Syngas to Alcohols over $0.5 \mathrm{Pd} / \mathrm{FeCoCu}$ Catalyst.

1.18 CO Conversion and Selectivities as a Function of Pressure for the HZSM$5+0.5 \mathrm{Pd} / \mathrm{FeCuCo}$ Mixture

1.19 CO Conversion and Selectivities as a Function of the GHSV for HZSM-5+0.5Pd/FeCuCo Mixture.

1.20 CO Conversion and Selectivities as a Function of the HZSM-5/0.5Pd/FeCoCu Ratio for $\mathrm{H}_{2} / \mathrm{CO}=1, \mathrm{~T}=300^{\circ} \mathrm{C}, \mathrm{P}=70$ bars, GHSV $=3000 \mathrm{~h}^{-1}$ 


\section{Tables}

1.1 BET Surface Area, Ni Particle Sizes and Percentage of Coke Present on the Catalysts after the Stability Test for CO Methanation (no sorbent included).

1.2 One-Step Conversion of Syngas to Fuels.

1.3 Effect of Reaction Parameters (i.e., GHSV, temperature, pressure and HZSM-5: $0.5 \mathrm{Pd} / \mathrm{FeCoCu}$ weight ratio) on $\mathrm{CO}$ Conversion, Selectivities, Hydrocarbon Distribution, and $\mathrm{C} 5+$ Yield for the HZSM-5/0.5Pd/FeCoCu Mixture and Reactivity of the $0.5 \mathrm{Pd} / \mathrm{FeCoCu}$ HAS Catalysts without HZSM-5 Addition

1.4 Comparison of the Catalytic Performance of the HZSM-5+0.5Pd/FeCoCu Mixture for the One-Step Process and the Two-Step Process. 


\section{Task 3.3: Warm Syngas Cleanup and Catalytic Processes for Syngas Conversion to Fuels}

\section{Subtask 3: Advanced Syngas Conversion Technologies}

This collaborative joint research project is in the area of advanced gasification and conversion, within the Chinese Academy of Sciences (CAS)-National Energy Technology Laboratory (NETL)-Pacific Northwest National Laboratory (PNNL) Memorandum of Understanding. The goal for this subtask is the development of advanced syngas conversion technologies. Two areas of investigation were evaluated:

\section{Sorption-Enhanced Synthetic Natural Gas Production from Syngas}

The conversion of synthetic gas (syngas) to synthetic natural gas (SNG) is typically catalyzed by nickel catalysts performed at moderate temperatures $\left(275\right.$ to $\left.325^{\circ} \mathrm{C}\right)$. The reaction is highly exothermic and substantial heat is liberated, which can lead to process thermal imbalance and destruction of the catalyst. As a result, conversion per pass is typically limited, and substantial syngas recycle is employed. Commercial methanation catalysts and processes have been developed by Haldor Topsoe, and in some reports, they have indicated that there is a need and opportunity for thermally more robust methanation catalysts to allow for higher per-pass conversion in methanation units. SNG process requires the syngas feed with a higher $\mathrm{H}_{2} / \mathrm{CO}$ ratio than typically produced from gasification processes. Therefore, the watergas shift reaction (WGS) will be required to tailor the $\mathrm{H}_{2} / \mathrm{CO}$ ratio. Integration with $\mathrm{CO}_{2}$ separation could potentially eliminate the need for a separate WGS unit, thereby integrating WGS, methanation, and $\mathrm{CO}_{2}$ capture into one single unit operation and, consequently, leading to improved process efficiency. The SNG process also has the benefit of producing a product stream with high $\mathrm{CO}_{2}$ concentrations, which makes $\mathrm{CO}_{2}$ separation more readily achievable. The use of either adsorbents or membranes that selectively separate the $\mathrm{CO}_{2}$ from the $\mathrm{H}_{2}$ and $\mathrm{CO}$ would shift the methanation reaction (by driving WGS for hydrogen production) and greatly improve the overall efficiency and economics of the process. The scope of this activity was to develop methods and enabling materials for syngas conversion to SNG with readily $\mathrm{CO}_{2}$ separation.

Suitable methanation catalyst and $\mathrm{CO}_{2}$ sorbent materials were developed. Successful proof-ofconcept for the combined reaction-sorption process was demonstrated, which culminated in a research publication. With successful demonstration, a decision was made to switch focus to an area of fuels research of more interest to all three research institutions (CAS-NETL-PNNL).

\section{Syngas-to-Hydrocarbon Fuels through Higher Alcohol Intermediates}

There are two types of processes in syngas conversion to fuels that are attracting R\&D interest: 1) syngas conversion to mixed alcohols; and 2) syngas conversion to gasoline via the methanol-togasoline process developed by Exxon-Mobil in the 1970s. The focus of this task was to develop a one-step conversion technology by effectively incorporating both processes, which is expected to reduce the capital and operational cost associated with the conversion of coal-derived syngas to liquid fuels. It should be noted that this work did not further study the classic Fischer-Tropsch reaction pathway. Rather, we focused on the studies for unique catalyst pathways that involve the direct liquid fuel synthesis enabled by oxygenated intermediates. Recent advances made in the area of higher alcohol synthesis including the novel catalytic composite materials recently developed by CAS using base metal catalysts were used. 


\subsection{Research Objectives}

\subsection{Research and Development Activities}

The sorption-enhanced synthetic natural gas (SNG) production from synthetic gas (syngas) activity had the following objectives:

- Develop highly-stable methanation catalysts

- Develop active $\mathrm{CO}_{2}$ sorbent materials also compatible with the methanation catalysts

- Develop novel reactors to fully integrate methanation, water-gas shift (WGS), and $\mathrm{CO}_{2}$ capture.

The syngas-to-hydrocarbon fuels through higher alcohol intermediates activity had the following objectives:

- Develop highly active and selective catalysts and develop innovative catalytic processes for direct conversion of syngas to gasoline based on the methanol-to-gasoline process route.

- Use advanced characterization tools and surface science techniques to understand the nature of catalytic sites, and provide the guidance in the development of improved and multifunctional catalysts for direct conversion of syngas to fuels with the space time yields required for commercial viability.

- Because no third-year funding support was available for the project, research activities stopped prior to reaching the final deliverables. Experimental data useful for scale-up and techno-economic analysis for the process was to be made along with a go/no-go decision to decide if further development of the one-step conversion process was warranted for the design and demonstration of pilot scale test at Chinese Academy of Sciences (CAS) facilities in LianYunGang, China.

\subsubsection{Sorption-Enhanced Synthetic Natural Gas Production from Syngas}

\subsubsection{Thermodynamics of the CO Methanation Reaction in the Absence or Presence of $\mathrm{CO}_{2}$ Sorption}

The $\mathrm{CO}$ methanation reaction is a process that is limited by thermodynamic equilibrium. Calculating chemical equilibrium using equations (1) and (2) provides the thermodynamic composition for the system assuming only these reactions occur. As shown in Figure 1.1, for a molar feed composition of $\mathrm{H}_{2} / \mathrm{CO}=1$, $\mathrm{CO}$ conversion decreases as the reaction temperatures increases. For example, $\mathrm{CO}$ conversion decreases from $97 \%$ to $52 \%$ when temperature increases from $350^{\circ} \mathrm{C}$ to $600^{\circ} \mathrm{C}$. Equilibrium selectivities for both $\mathrm{CO}_{2}$ and $\mathrm{CH}_{4}$ are shown in Figure 1.1 as well. At $350^{\circ} \mathrm{C}$ the selectivity to $\mathrm{CO}_{2}$ and $\mathrm{CH}_{4}$ are each approximately $50 \%$. With increasing temperature, selectivity to $\mathrm{CO}_{2}$ decreases as the WGS reaction (Eq. 2) is disfavored. At $600^{\circ} \mathrm{C}$, equilibrium selectivities to methane and $\mathrm{CO}_{2}$ are approximately $56 \%$ and $44 \%$, respectively.

$$
\begin{aligned}
& \mathrm{CO}+3 \mathrm{H}_{2} \leftrightarrow \mathrm{H}_{2} \mathrm{O}+\mathrm{CH}_{4} \\
& \mathrm{CO}+\mathrm{H}_{2} \mathrm{O} \leftrightarrow \mathrm{CO}_{2}+\mathrm{H}_{2}
\end{aligned}
$$




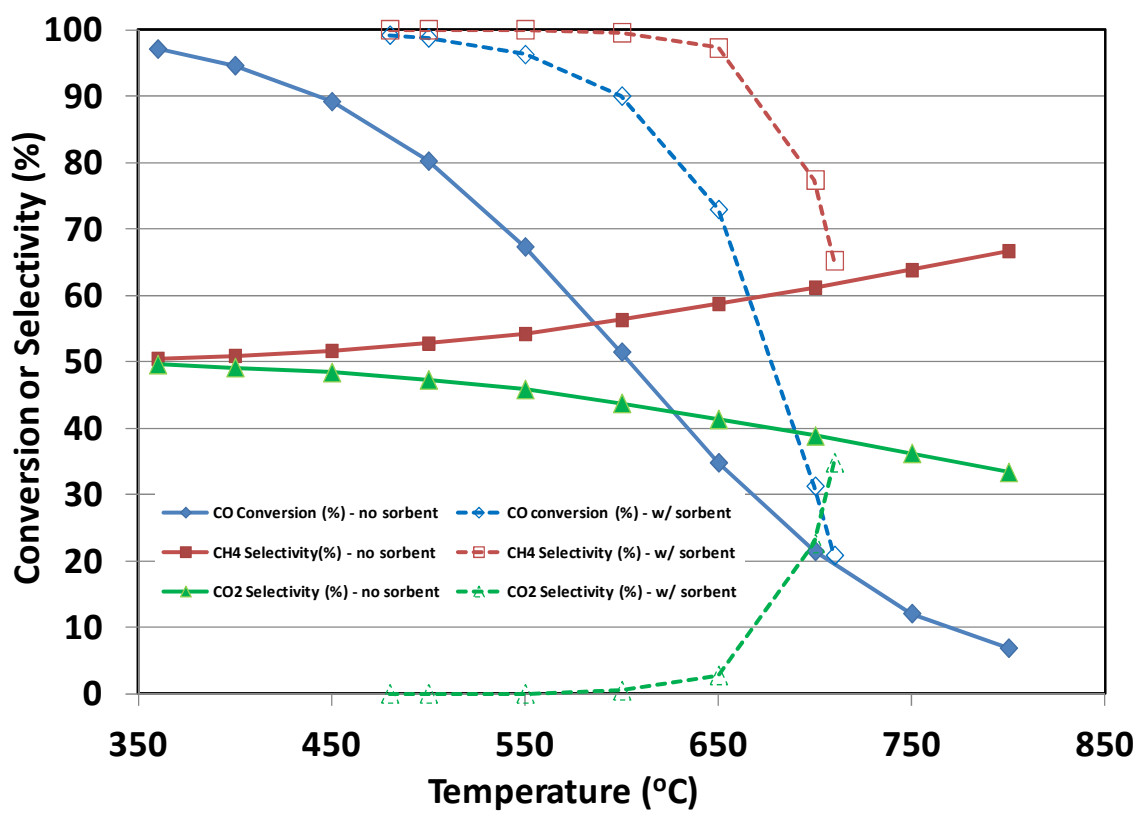

Figure 1.1. Equilibrium $\mathrm{CO}$ Conversion, $\mathrm{CH}_{4}$ Selectivity, and $\mathrm{CO}_{2}$ Selectivity as a Function of Temperature, Calculated either in the Absence or Presence of Sorbent $(\mathrm{P}=1 \mathrm{~atm}$, molar composition: $\mathrm{H}_{2}=48 \%, \mathrm{CO}=48 \%, \mathrm{~N}_{2}=4 \%$ )

The thermodynamic benefit of adding $\mathrm{CO}_{2}$ sorption to the system is illustrated by integrating all three reactions: $\mathrm{CO}$ methanation (Eq. 1), WGS (Eq. 2), and $\mathrm{CO}_{2}$ sorption (Eq. 3).

$$
\mathrm{CaO}+\mathrm{CO}_{2} \leftrightarrow \mathrm{CaCO}_{3}
$$

By incorporating Eq. (3) to the reaction system, $\mathrm{CO}_{2}$ is selectively removed by $\mathrm{CaO}$ adsorption, forming $\mathrm{CaCO}_{3}$, and WGS reaction is highly favored. As shown in Figure 1.1, even at $600^{\circ} \mathrm{C}, \mathrm{CO}$ conversion is still relatively high at approximately $90 \%$. Also at $600^{\circ} \mathrm{C}$, selectivities to $\mathrm{CH}_{4}$ and $\mathrm{CO}_{2}$ are approximately $99.5 \%$ and $0.5 \%$, respectively. Such high equilibrium selectivity to methane is highly desired for this process. As the temperature further increases from $600^{\circ} \mathrm{C}$ to $700^{\circ} \mathrm{C}$, selectivity to $\mathrm{CH}_{4}$ quickly decreases and approaches the value at which no $\mathrm{CO}_{2}$ sorption was included in the equilibrium calculations because $\mathrm{CaO}$ carbonation to form $\mathrm{CaCO}_{3}$ (Eq.3) is disfavored at such a high temperature. Hence, operating at $600^{\circ} \mathrm{C}$ seems to be an appropriate condition to obtain high yields of methane. This is also an optimal temperature for CaO-based sorbents to perform well (Shimizu et al. 1999, Li et al. 2010, Hughes et al. 2004). Before experimental proof-of-concept demonstration of this novel process, we have thus examined the performance and properties of the $68 \% \mathrm{CaO} / \mathrm{MgAl}_{2} \mathrm{O}_{4}$ for $\mathrm{CO}_{2}$ sorption at $600^{\circ} \mathrm{C}$.

\section{$\underline{\mathrm{CO}_{2}} \underline{\text { Sorbent Performance Results and Characterization }}$}

Three carbonation-decarbonation cycles were conducted to evaluate the performance of the $68 \% \mathrm{CaO} / \mathrm{MgAl}_{2} \mathrm{O}_{4}$ sorbent at $600^{\circ} \mathrm{C}$. Figure 1.2 depicts the amount of $\mathrm{CO}_{2}$ detected from the gas phase as a function of the time on-stream (TOS) during the carbonation step for each cycle. For the first cycle, $\mathrm{CO}_{2}$ was not detected for the first $12 \mathrm{~min}$, indicating that $\mathrm{CO}_{2}$ was adsorbed during this time. After 12 min, $\mathrm{CO}_{2}$ was detected from the gas phase, signifying that the sorbent had reached its $\mathrm{CO}_{2}$ sorption capacity. The $\mathrm{CO}_{2}$ sorption capacity of the sorbent for this first cycle was thus estimated to be $\sim 32 \mathrm{wt} . \%$. After that, the sorbent was heated to $800^{\circ} \mathrm{C}$ under $\mathrm{N}_{2}$ flow and held for $1 \mathrm{hr}$ at this temperature for total 
decarbonation. Then, to examine the durability of the sorbent, a second cycle of carbonationdecarbonation was conducted under the same conditions. As can be seen from Figure 1.2, $\mathrm{CO}_{2}$ was detected from the gas phase after only 9 min on-stream. This shows that the $\mathrm{CO}_{2}$ sorption capacity of the sorbent decreased and it deactivated to some extent. The $\mathrm{CO}_{2}$ sorption capacity of the sorbent for this second cycle was only $\sim 24 \mathrm{wt} \%$. The decrease in activity of $\mathrm{CaO}$ sorbents after multiple cycles has been reported (Abanades and Alvarez 2003, Albrecht et al. 2008, Manovic and Anthony 2007). Abanades and Alvarez (2007) attributed the decrease in activity, for an untreated limestone (i.e., $\mathrm{CaO}$ ), to sintering as the number of carbonation-decarbonation cycles increase. Hughes et al. (2004), Manovic and Anthony (2007), and Anthony et al. have shown that $\mathrm{CaO}$ sorbent can be reactivated by steam treatment under pressure. To test the regenerability of the $68 \% \mathrm{CaO} / \mathrm{MgAl}_{2} \mathrm{O}_{4}$ sorbent, we have thus carried out a third carbonation-decarbonation cycle with either $\mathrm{H}_{2} \mathrm{O}$ addition to the feed during the carbonation step or $\mathrm{H}_{2} \mathrm{O}$ treatment before carbonation. Figure 1.2 presents the results obtained for the third cycle when $\mathrm{H}_{2} \mathrm{O}$ (17 mol\%) was added to the feed during the carbonation step. $\mathrm{CO}_{2}$ was not detected during the first 13 min indicating that it was reactivated in the presence of $\mathrm{H}_{2} \mathrm{O}$. Indeed, the $\mathrm{CO}_{2}$ sorbent capacity for the third cycle was $\sim 34 \mathrm{wt} \%$ and quite similar to the one observed for the first cycle. Note that the same results were obtained when $\mathrm{H}_{2} \mathrm{O}$ treatment was conducted before the carbonation.

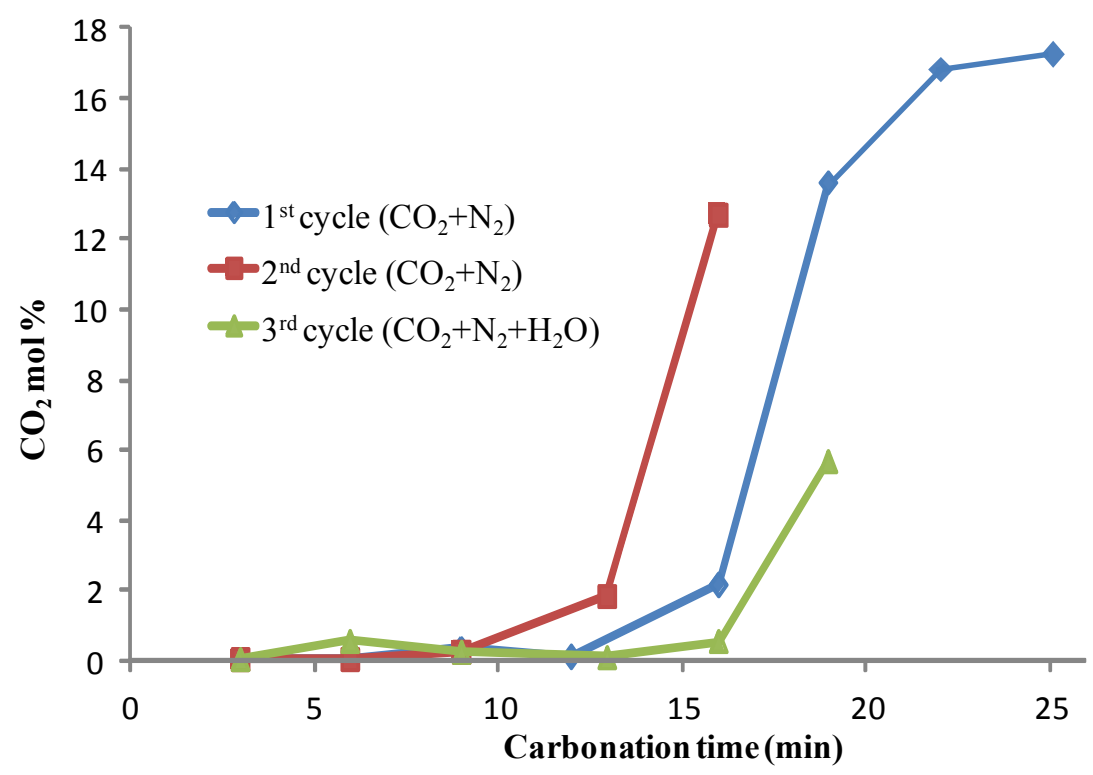

Figure 1.2. Evolution of the $\mathrm{CO}_{2} \mathrm{Mol} \%$ Detected from Micro-Gas Chromatography Analysis as a Function of the Carbonation Time. $\mathrm{T}=600^{\circ} \mathrm{C}, 23 \% \mathrm{CO}_{2} / \mathrm{N}_{2}$ (i.e., $4.7 \mathrm{sccm} \mathrm{CO}$, $15.6 \mathrm{sccm} \mathrm{N} \mathrm{N}_{2}$ ), sorbent $=0.35 \mathrm{~g}$. For the third cycle, $\mathrm{H}_{2} \mathrm{O}$ was added to the feed $\left(19 \% \mathrm{CO}_{2}=4.7 \mathrm{sccm}, 64 \% \mathrm{~N}_{2}=16.7 \mathrm{sccm}\right.$ and $\left.17 \% \mathrm{H}_{2} \mathrm{O}=4.2 \mathrm{sccm}\right)$.

Figure 1.3 shows XRD patterns recorded for the $68 \% \mathrm{CaO} / \mathrm{MgAl}_{2} \mathrm{O}_{4}$ sorbent, before any carbonationdecarbonation cycle (labeled as "fresh"), after the first carbonation, and after each carbonationdecarbonation cycle, between $2 \theta=15-70^{\circ}$. As expected, the XRD pattern recorded for the fresh sorbent presents mainly peaks characteristic of $\mathrm{CaO}$ and $\mathrm{MgAl}_{2} \mathrm{O}_{4}$. Small peaks due to $\mathrm{Ca}(\mathrm{OH})_{2}$ and $\mathrm{CaCO}_{3}$ also were observed, which can be attributed to the exposure of the sorbent to the atmosphere. The XRD 


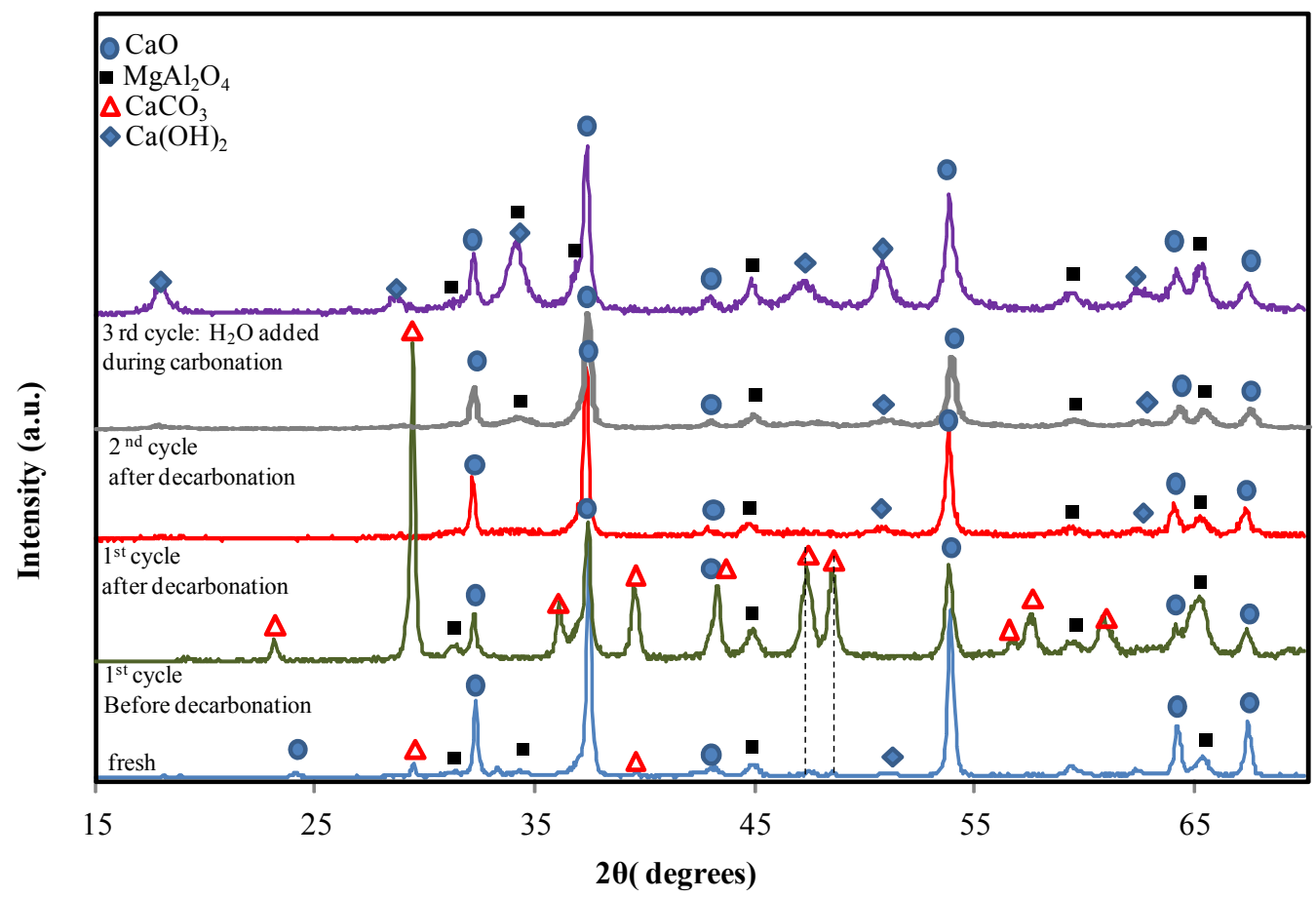

Figure 1.3. XRD Patterns Recorded for the $68 \% \mathrm{CaO} / \mathrm{MgAl}_{2} \mathrm{O}_{4}$ Sorbent before any CarbonationDecarbonation Cycle Labeled as "Fresh," after Carbonation for the First Cycle, and after Decarbonation for Each Cycle

pattern obtained after the first carbonation (i.e., before decarbonation) shows peaks attributed to $\mathrm{CaCO}_{3}$, due to the transformation $\mathrm{CaO} \rightarrow \mathrm{CaCO}_{3}$. Peaks due to $\mathrm{CaO}$ are observed as well, suggesting that during the carbonation $\mathrm{CaO}$ was not completely utilized. This is consistent with our previous study showing a $63 \%$ utilization of $\mathrm{CaO}$ with a similar $68 \% \mathrm{CaO} / \mathrm{MgAl}_{2} \mathrm{O}_{4}$ sorbent ( $\mathrm{Li}$ et al. 2010). The subsequent decarbonation step of the sorbent leads to a complete transformation of $\mathrm{CaCO}_{3}$ to $\mathrm{CaO}$ because no peaks characteristic of the carbonate species are present in the XRD pattern (see Figure 3). Note that very small peaks due to $\mathrm{Ca}(\mathrm{OH})_{2}$ were observed; these peaks likely are due to the exposure of the sorbent to the atmosphere (upon subsequent handling). The XRD patterns recorded after the second carbonation/ decarbonation cycle are similar to the pattern recorded after the first carbonation/decarbonation cycle. The XRD pattern obtained after the third carbonation-decarbonation cycle shows the intense peaks that are attributed to $\mathrm{CaO}$ and $\mathrm{Ca}(\mathrm{OH})_{2}$ as well as peaks due to $\mathrm{MgAl}_{2} \mathrm{O}_{4}$. Addition of $\mathrm{H}_{2} \mathrm{O}$ to the feed during the third carbonation cycle led to the (partial) transformation of $\mathrm{CaO}$ to $\mathrm{Ca}(\mathrm{OH})_{2}$. After the third carbonation/decarbonation cycle, the $\mathrm{CaO}$ crystallite size was equal to $26 \mathrm{~nm}$, which was lower than the $\mathrm{CaO}$ crystallite size after the first carbonation/decarbonation cycle (i.e., $36 \mathrm{~nm}$ ). Hence, adding $\mathrm{H}_{2} \mathrm{O}$ to the feed prevented the sintering of $\mathrm{CaO}$ and resulted in smaller $\mathrm{CaO}$ particles. These results agree with those obtained by Hughes et al. (2004), who showed that hydration of limestone leads to the formation of cracks in the lime particles and thus an increase of the surface area and the pore volume. A separate experiment in which $\mathrm{H}_{2} \mathrm{O}$ treatment was conducted before the third carbonation/decarbonation cycle has also shown that the sorbent was also efficiently regenerated upon hydration. These results suggest that for multiple carbonation-decarbonation cycles, deactivation of the $68 \% \mathrm{CaO} / \mathrm{MgAl}_{2} \mathrm{O}_{4}$ sorbent could be prevented by adding $\mathrm{H}_{2} \mathrm{O}$ to the feed during carbonation. This can be readily practiced because the water content is between $5 \%$ and $20 \%$ in a coal-derived synthesis gas (syngas) depending on the gasifier and type of coal used as the feedstock (DOE 2000). 


\subsubsection{Integrated CO methanation, WGS, and $\mathrm{CO}_{2}$ Capture}

\section{$\underline{\text { Integrated Sorption-Reaction }}$}

Proof-of-concept studies for integrating $\mathrm{CO}$ methanation with $\mathrm{CO}_{2}$ capture were performed using $20 \% \mathrm{Ni} / \mathrm{SiC}$. $\mathrm{SiC}$ was expected to be a more appropriate support for exothermic reactions because of its superior thermal stability and high thermal conductivity. These integrated tests were performed at $600^{\circ} \mathrm{C}$ with the $68 \% \mathrm{CaO} / \mathrm{MgAl}_{2} \mathrm{O}_{4}$ sorbent mixed with the catalyst. For reasons described above, $\mathrm{H}_{2} \mathrm{O}$ was included in the feed such that the total feed composition was $38.4 \% \mathrm{H}_{2}, 38.4 \% \mathrm{CO}, 20 \% \mathrm{H}_{2} \mathrm{O}$, and $3.2 \% \mathrm{~N}_{2}$. A syngas ratio of 1 was chosen to reflect the $\mathrm{H}_{2} / \mathrm{CO}$ ratio of the gas mixture coming out of the gasifier even though lower ratios are likely to favor coking of the catalyst. Integrated testing results are shown as a function of time-on-stream in Figure 1.4. CO conversion of $>95 \%$ and selectivity to methane of $>98 \%$ were achieved and maintained for at least 20 min on-stream. Thus, the $\mathrm{CO}_{2}$ formed was efficiently adsorbed by $\mathrm{CaO}$, and the mixed sorbent-catalyst system was efficient under these conditions to convert $\mathrm{CO}$ to $\mathrm{CH}_{4}$. After approximately 25 min on-stream, the sorbent became saturated with $\mathrm{CO}_{2}$, and we calculated that the sorbent reached a $\mathrm{CO}_{2}$ capacity of $\sim 34 \mathrm{wt} \%$, which approximates that reported previously in the case of $\mathrm{CO}_{2}$ capture alone ( $\mathrm{Li}$ et al. 2010). Upon reaching $\mathrm{CO}_{2}$ sorption capacity, $\mathrm{CO}$ conversion and $\mathrm{CH}_{4}$ selectivity dropped to $31 \%$ and $58 \%$, respectively, approaching the equilibrium values.

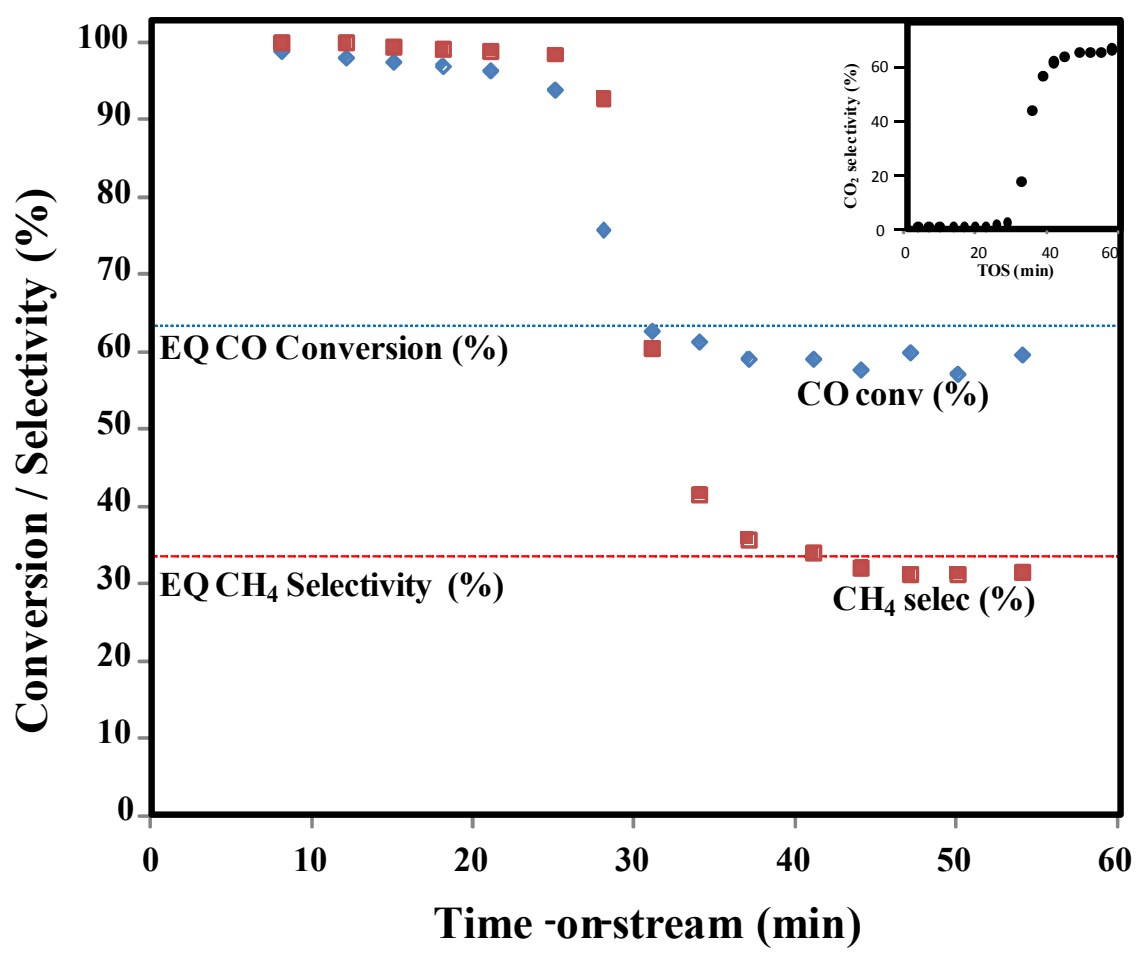

Figure 1.4. Integrated Sorption-Reaction Demonstration $\left(\mathrm{T}=600^{\circ} \mathrm{C}, \mathrm{P}=1 \mathrm{~atm}\right.$, gas hourly space velocity $(\mathrm{GHSV})=22,000 \mathrm{hr}^{-1}$, molar feed composition: $\mathrm{H}_{2}=38.4 \%, \mathrm{CO}=38.4 \%$, $\mathrm{H}_{2} \mathrm{O}=20 \%, \mathrm{~N}_{2}=3.2 \%$; catalyst $=0.1 \mathrm{~g}[20 \% \mathrm{Ni} / \mathrm{SiC}]$, sorbent $=0.7 \mathrm{~g}, \mathrm{SiC}=3.0 \mathrm{~g}$ [diluent]). $\mathrm{CO}$ conversion and $\mathrm{CH}_{4}$ selectivity are presented in the main figure whereas $\mathrm{CO}_{2}$ selectivity is presented in the inset, as a function of the TOS. 
Figure 1.5 further illustrates these results in terms of $\mathrm{CH}_{4}$ yield. Note that the $\mathrm{CH}_{4}$ yield was calculated from the $\mathrm{CO}$ conversion and the gas phase $\mathrm{CH}_{4}$ selectivity. A significantly high $\mathrm{CH}_{4}$ yield (92\%) was observed for the integrated test, as compared to the methane yield of $18 \%$ under reaction-only conditions (without $\mathrm{CO}_{2}$ sorption), which is close to an equilibrium yield of $\sim 22 \%$. These results highlight the performance benefits realized when the kinetics of $\mathrm{CO}_{2}$ uptake and methanation are properly matched.

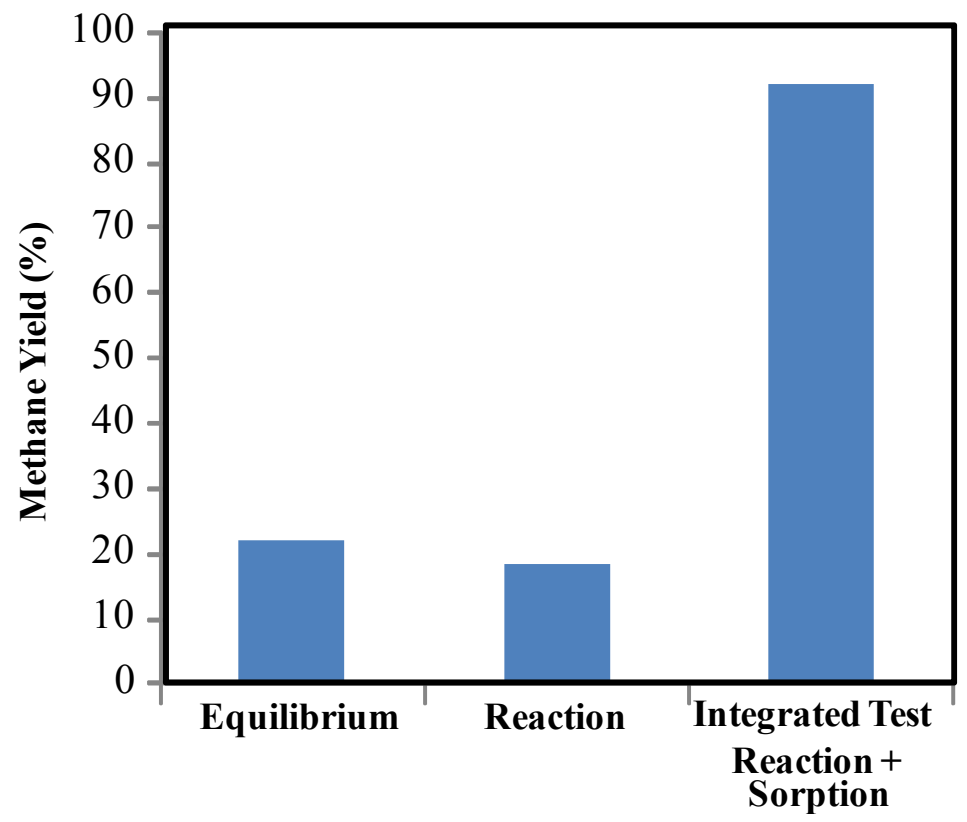

Figure 1.5. Methane Yield Comparison with and without $\mathrm{CO}_{2}$ Sorption $\left(\mathrm{T}=600^{\circ} \mathrm{C}, \mathrm{P}=1 \mathrm{~atm}\right.$, GHSV $=22,000 \mathrm{hr}^{-1}$, feed composition: $\mathrm{H}_{2}=38.4 \%, \mathrm{CO}=38.4 \%, \mathrm{H}_{2} \mathrm{O}=20 \%, \mathrm{~N}_{2}=3.2 \%$; catalyst $=0.1 \mathrm{~g}[20 \% \mathrm{Ni} / \mathrm{SiC}]$, sorbent $=0.7 \mathrm{~g}, \mathrm{SiC}=3.0 \mathrm{~g}$ [diluent $])$

\section{Cycling experiments}

The cyclic stability of both catalyst and sorbent for the integrated test was evaluated in the multiple carbonation/decarbonation cycle studies. Carbonation was conducted under $\mathrm{CO}$ methanation reaction conditions at $600^{\circ} \mathrm{C}$ for $1 \mathrm{hr}$. Decarbonation was carried out at $800^{\circ} \mathrm{C}$ by flowing $50 \mathrm{sccm}$ of $\mathrm{N}_{2}$ for $1 \mathrm{hr}$. The $20 \% \mathrm{Ni} / \mathrm{SiC}$ catalyst was found to be unsuitable for cyclic studies because not only the initial CO conversion after the first carbonation/decarbonation cycle reduced significantly $(\sim 28 \%)$ but it also deactivated during the second carbonation cycle as shown in Figure 1.6. The deactivation during cycle 2 is attributed to the formation of amorphous carbon (see transmission electron microscopy [TEM] image in Figure 1.7). We have thus conducted these multiple carbonation-decarbonation cycles with the $20 \% \mathrm{Ni} / \mathrm{Al}_{2} \mathrm{O}_{3}$ catalyst. Figure 1.8 presents the $\mathrm{CO}$ conversion and $\mathrm{CH}_{4}$ selectivity obtained for multiple carbonation-decarbonation cycles over the $20 \% \mathrm{Ni} / \mathrm{Al}_{2} \mathrm{O}_{3}$ catalyst. The $\mathrm{CO}$ conversion decreases from $90 \%$ for the first cycle to $65 \%$ for the fifth cycle indicating that the catalyst suffers from deactivation. Note that the $\mathrm{CH}_{4}$ selectivity was stable and equal to about $99 \%$ for each cycle indicating no significant deactivation of the sorbent. Because both $20 \% \mathrm{Ni} / \mathrm{SiC}$ and $20 \% \mathrm{Ni} / \mathrm{Al}_{2} \mathrm{O}_{3}$ suffer from deactivation when the integrated test is repeated for multiple cycles, we examined the stability of the $20 \% \mathrm{Ni} / \mathrm{MgAl}_{2} \mathrm{O}_{4}$ catalyst. We found that, with this catalyst, $\mathrm{CO}$ conversion is higher for the first cycle (i.e., $88 \%$ ) than for the second cycle (i.e., 69\%) (Figure 1.9). This is due to sintering of the Ni particles after decarbonation at 
$800^{\circ} \mathrm{C}$. The XRD analysis has shown that after reduction at $600^{\circ} \mathrm{C}$ the Ni particle size was less than $2 \mathrm{~nm}$ and after further treatment under $\mathrm{N}_{2}$ at $800^{\circ} \mathrm{C}$ for $1 \mathrm{hr}$ the Ni particles size increased to $6.8 \mathrm{~nm}$. However, from cycle 2 to cycle 14, significantly less deactivation was observed, as the conversion decreased only from $69 \%$ to $61 \%$. The $20 \% \mathrm{Ni} / \mathrm{MgAl}_{2} \mathrm{O}_{4}$ catalyst appears to be a more suitable catalyst for the integrated $\mathrm{CO}$ methanation with $\mathrm{CO}_{2}$ sorption. One can also note that the sorbent efficiency is not significantly altered as the $\mathrm{CH}_{4}$ selectivity decreased only from $99 \%$ after cycle 1 to $96.5 \%$ after cycle 14 .

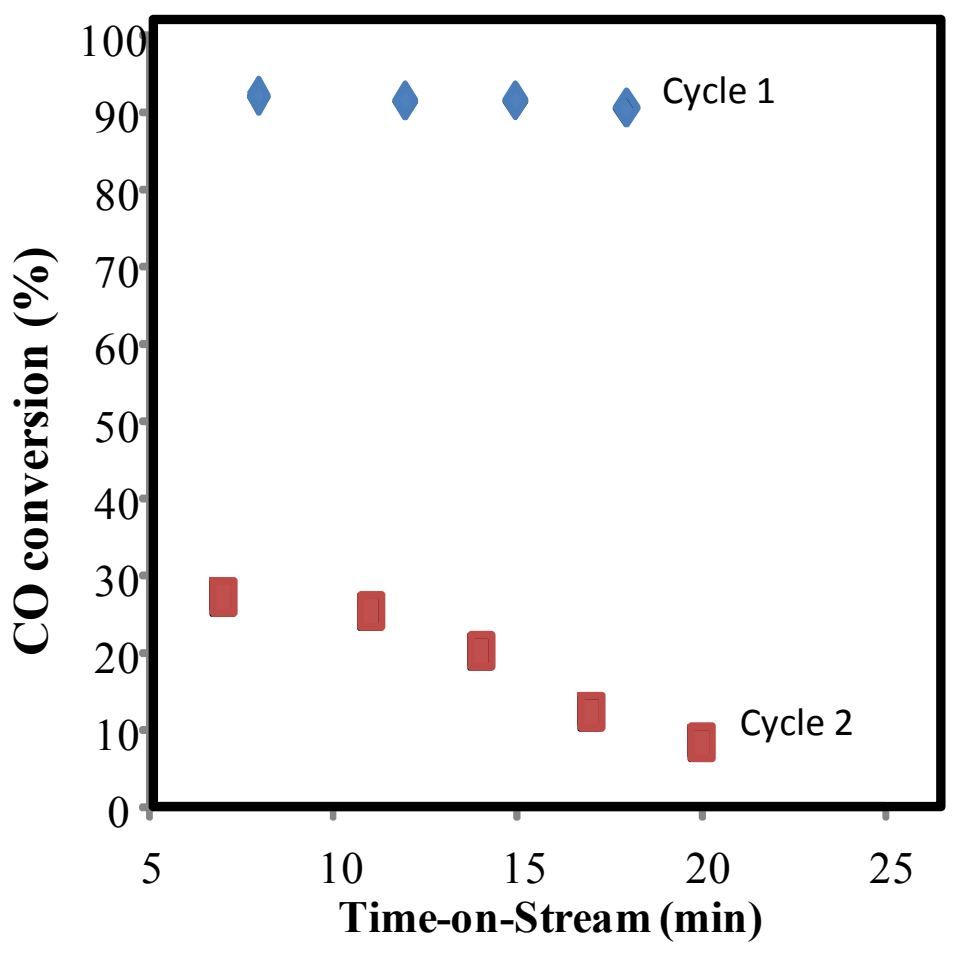

Figure 1.6. CO Conversion as a Function of the Time-On-Stream for the First Two Cycles using the $20 \% \mathrm{Ni} / \mathrm{SiC}$ Catalyst and $68 \% \mathrm{CaO} / \mathrm{MgAl}_{2} \mathrm{O}_{4}$ Sorbent $\left(\mathrm{T}=600^{\circ} \mathrm{C}, \mathrm{P}=1 \mathrm{~atm}\right.$, GHSV $=22,000 \mathrm{hr}^{-1}$, molar feed composition: $\mathrm{H}_{2}=38.4 \%, \mathrm{CO}=38.4 \%, \mathrm{H}_{2} \mathrm{O}=20 \%$, $\mathrm{N}_{2}=3.2 \%$; catalyst $=0.1 \mathrm{~g}$, sorbent $=0.7 \mathrm{~g}$ )
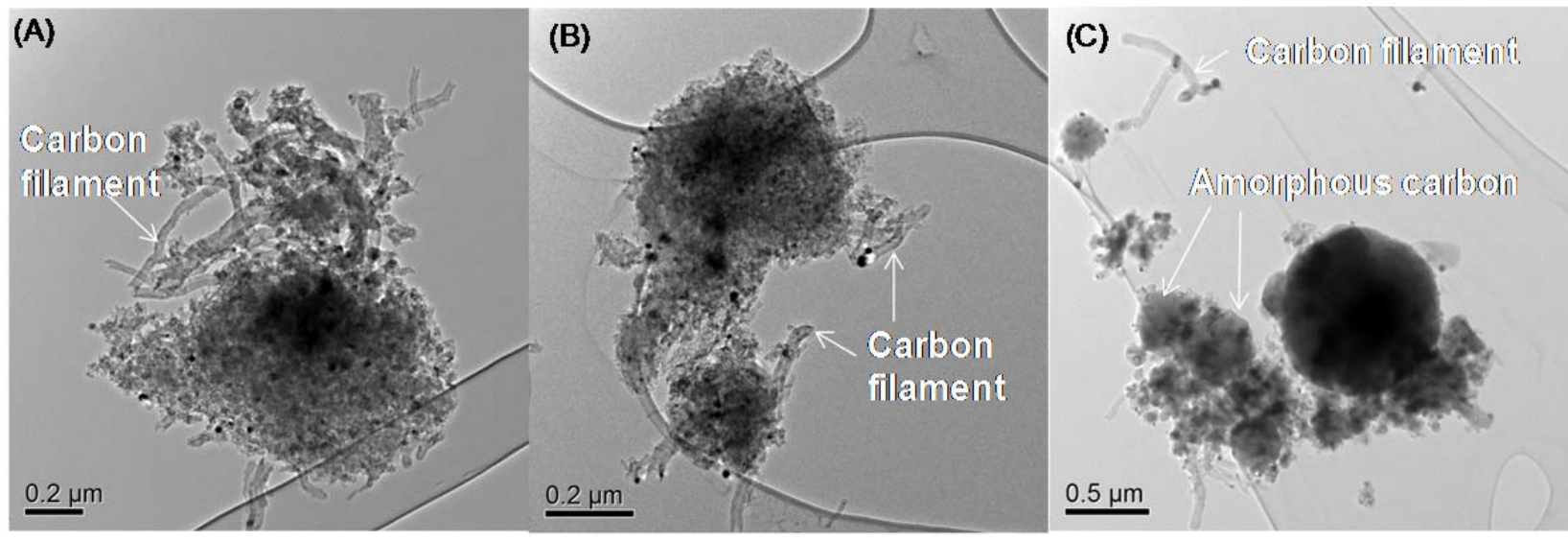

Figure 1.7. TEM Images for (A) the Spent $20 \% \mathrm{Ni} / \mathrm{Al} 2 \mathrm{O} 3$, (B) $20 \% \mathrm{Ni} / \mathrm{MgAl}_{2} \mathrm{O}_{4}$, and (C) $20 \% \mathrm{Ni} / \mathrm{SiC}$ 


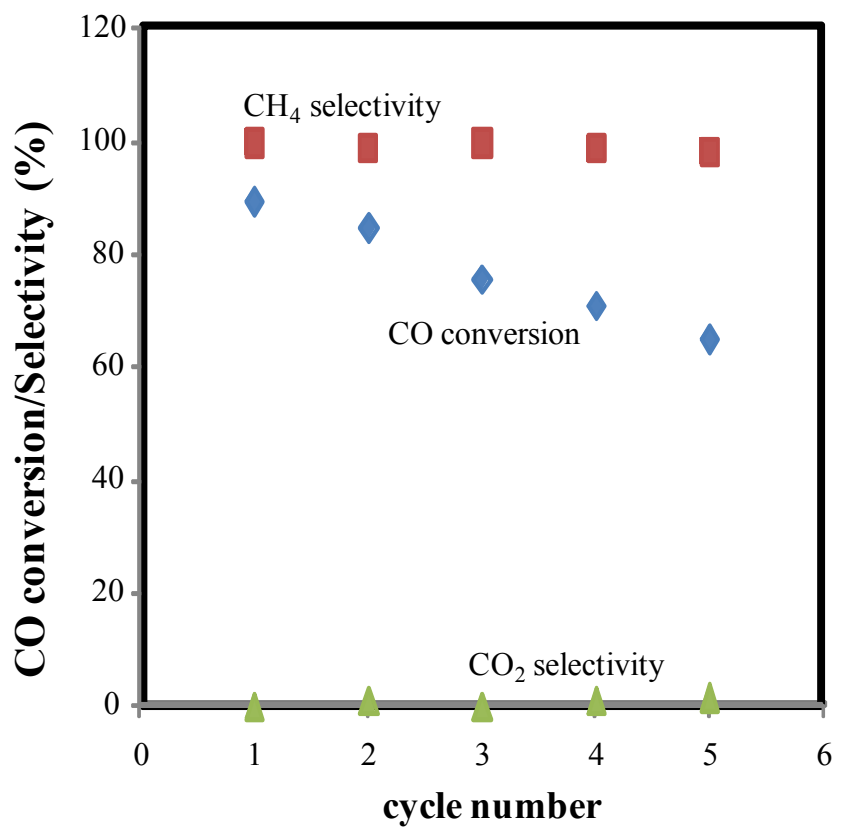

Figure 1.8. CO Conversion, $\mathrm{CH} 4$, and $\mathrm{CO} 2$ Selectivities for Each Carbonation/Decarbonation Cycle, for the $20 \% \mathrm{Ni} / \mathrm{Al} 2 \mathrm{O} 3$ Catalyst and $68 \% \mathrm{CaO} / \mathrm{MgAl}_{2} \mathrm{O}_{4}$ Sorbent $(\mathrm{T}=600 \mathrm{oC}, \mathrm{P}=1 \mathrm{~atm}$, GHSV $=22,000 \mathrm{hr}-1$, molar feed composition: $\mathrm{H}_{2}=38.4 \%, \mathrm{CO}=38.4 \%, \mathrm{H}_{2} \mathrm{O}=20 \%$, $\mathrm{N}_{2}=3.2 \%$; catalyst $=0.1 \mathrm{~g}$, sorbent $=0.7 \mathrm{~g}$ )

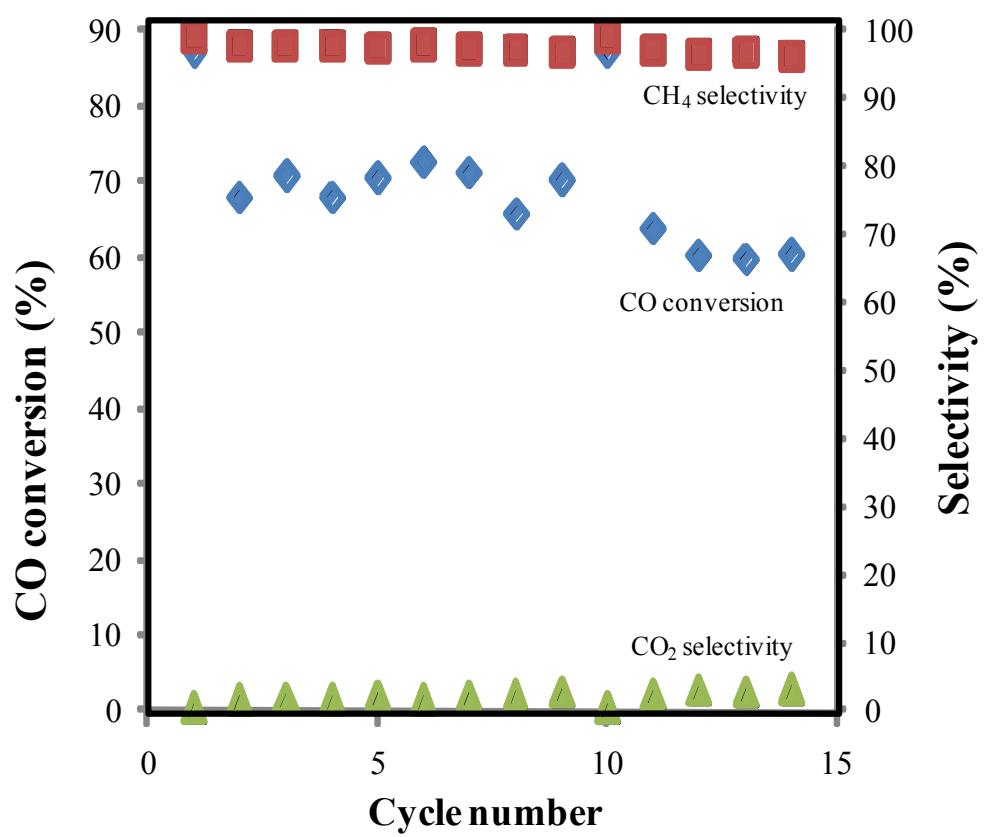

Figure 1.9. CO Conversion, $\mathrm{CH} 4$, and $\mathrm{CO} 2$ Selectivities for each Carbonation/Decarbonation Cycle, for the $20 \% \mathrm{Ni} / \mathrm{MgAl}_{2} \mathrm{O}_{4}$ Catalyst and $68 \% \mathrm{CaO} / \mathrm{MgAl}_{2} \mathrm{O}_{4}$ Sorbent $(\mathrm{T}=600 \mathrm{oC}, \mathrm{P}=1 \mathrm{~atm}$, $\mathrm{GHSV}=22,000 \mathrm{hr}-1$, molar feed composition: $\mathrm{H}_{2}=38.4 \%, \mathrm{CO}=38.4 \%, \mathrm{H}_{2} \mathrm{O}=20 \%$, $\mathrm{N}_{2}=3.2 \%$; catalyst $=0.1 \mathrm{~g}$, sorbent $=0.7 \mathrm{~g}$ ) 
The rapid deactivation observed for the $20 \% \mathrm{Ni} / \mathrm{SiC}$ catalyst, compared to the $20 \% \mathrm{Ni} / \mathrm{Al}_{2} \mathrm{O}_{3}$ and $20 \% \mathrm{Ni} / \mathrm{MgAl}_{2} \mathrm{O}_{4}$ catalysts, was not expected. In a recent study, $\mathrm{Yu}$ et al. (2011) reported that a $15 \% \mathrm{Ni} / \mathrm{SiC}$ was significantly more stable than a $15 \% \mathrm{Ni} / \mathrm{TiO}_{2}$ for the $\mathrm{CO}$ methanation at $340^{\circ} \mathrm{C}$ and $\mathrm{H}_{2} / \mathrm{CO}=3 . \mathrm{SiC}$ has excellent thermal conductivity that is supposed to reduce gradients of temperature within catalysts particles and prevent metal particles from sintering that is responsible for deactivation (Yu et al. 2011). Because the results of the present study seem to disagree with the results reported in the literature, we examined the stability of the three catalysts under conventional $\mathrm{CO}$ methanation reaction conditions (i.e., without sorbent and $\mathrm{H}_{2} \mathrm{O}$ addition to the feed) and characterized the spent samples to understand the rapid deactivation of the $20 \% \mathrm{Ni} / \mathrm{SiC}$ and $20 \% \mathrm{Ni} / \mathrm{Al}_{2} \mathrm{O}_{3}$, compared to the $20 \%$ $\mathrm{Ni} / \mathrm{MgAl}_{2} \mathrm{O}_{4}$. The results are presented in the following sections.

\subsubsection{CO Methanation Catalytic Performance Results}

Stability of the $20 \% \mathrm{Ni} / \mathrm{Al}_{2} \mathrm{O}_{3}, 20 \% \mathrm{Ni} / \mathrm{MgAl}_{2} \mathrm{O}_{4}$, and $20 \% \mathrm{Ni} / \mathrm{SiC}$ catalysts for the $\mathrm{CO}$ methanation reaction without sorbent was investigated at $500^{\circ} \mathrm{C}$ using a gas mixture of $\mathrm{H}_{2}, \mathrm{CO}$, and $\mathrm{N}_{2}$. Note that, in order to mimic the conventional $\mathrm{CO}$ methanation reaction, $\mathrm{H}_{2} \mathrm{O}$ was not added to the gas mixture. The deactivation is significantly faster when the reaction is conducted at $600^{\circ} \mathrm{C}$ without $\mathrm{H}_{2} \mathrm{O}$ addition to the feed. Therefore, to better compare the stability of the three catalysts, the reaction was conducted at $500^{\circ} \mathrm{C}$. Figure 1.10 displays $\mathrm{CO}$ conversion as a function of TOS for all three catalysts. $20 \% \mathrm{Ni} / \mathrm{Al}_{2} \mathrm{O}_{3}$ and $20 \% \mathrm{Ni} / \mathrm{MgAl}_{2} \mathrm{O}_{4}$ catalysts exhibited higher initial activity but more rapid deactivation than $20 \% \mathrm{Ni} / \mathrm{SiC}$ catalyst. For example, CO conversion decreased from initial $88 \%$ to $\sim 40 \%$ (TOS $=25 \mathrm{hrs}$ ) and from initial $65 \%$ to $\sim 15 \%$ (TOS $=25 \mathrm{hrs}$ ) for the $20 \% \mathrm{Ni} / \mathrm{Al}_{2} \mathrm{O}_{3}$ and $20 \% \mathrm{Ni} / \mathrm{MgAl}_{2} \mathrm{O}_{4}$ catalysts, respectively. On the other hand, $20 \% \mathrm{Ni} / \mathrm{SiC}$ catalyst was more stable and the conversion decreased only from initial $\sim 35 \%$ to $\sim 26 \%$ (TOS $=25 \mathrm{hrs}$ ). These results are thus in agreement with the stability measurements conducted by $\mathrm{Yu}$ et al. (2011) showing improved stability when Ni is supported on SiC. To explain the decline in activity and the differences between the three catalysts, both the reduced and spent catalysts were characterized using XRD, TPO-TGA, and TEM.

\subsubsection{Characterization of the Reduced and Spent Catalysts}

The XRD patterns recorded for the catalysts after reduction and after the $\mathrm{CO}$ methanation stability test are displayed in Figure 1.11 and Figure 1.12, respectively. For the reduced catalysts, peaks characteristic of their support (i.e., $\gamma \mathrm{Al}_{2} \mathrm{O}_{3}, \mathrm{MgAl}_{2} \mathrm{O}_{4}$, or $\beta \mathrm{SiC}$ ) are present as well as peaks characteristic of $\mathrm{Ni}^{\circ}$ (Figure 1.11). No peaks due to $\mathrm{NiO}$ phase are present on the XRD patterns. $\mathrm{H}_{2}$-temperature programmed reduction profiles presented in Figure 1.11 show several peaks located between $200^{\circ} \mathrm{C}$ to $900^{\circ} \mathrm{C}$ attributed to different type of $\mathrm{NiO}$ species having different interaction with the support (Zhao et al.2012). The profiles show that after reduction at $600^{\circ} \mathrm{C}$, the $20 \% \mathrm{Ni} / \mathrm{Al}_{2} \mathrm{O}_{3}$ and the $20 \% \mathrm{Ni} / \mathrm{SiC}$ catalysts were fully reduced. Note that the peak located at $600^{\circ} \mathrm{C}$ for the $20 \% \mathrm{Ni} / \mathrm{SiC}$ catalyst is due to production of methane, from $\mathrm{H}_{2}$ and carbon impurities of the $\mathrm{SiC}$ support, because mass 16 was detected by mass spectrometry. For the $20 \% \mathrm{Ni} / \mathrm{MgAl}_{2} \mathrm{O}_{4}$, the reduction starts at $400^{\circ} \mathrm{C}$ and is complete at $800^{\circ} \mathrm{C}$ indicating that the $\mathrm{Ni}$ was not fully reduced after the reduction treatment at $600^{\circ} \mathrm{C}$. The $\mathrm{Ni}^{\circ}$ particle sizes calculated from the XRD patterns are presented in Table $1.1 .20 \% \mathrm{Ni} / \mathrm{SiC}$ catalyst contains larger $\mathrm{Ni}^{\circ}$ particles (i.e., $22 \mathrm{~nm}$ ) likely because of its lower surface area $\left(15 \mathrm{~m}^{2} / \mathrm{g}\right)$ compared to the $20 \% \mathrm{Ni} / \mathrm{Al}_{2} \mathrm{O}_{3}$ $\left(122 \mathrm{~m}^{2} / \mathrm{g}\right)$ and $20 \% \mathrm{Ni} / \mathrm{MgAl}_{2} \mathrm{O}_{4}\left(107 \mathrm{~m}^{2} / \mathrm{g}\right)$ catalysts. Although the $20 \% \mathrm{Ni} / \mathrm{MgAl}_{2} \mathrm{O}_{4}$ and $20 \% \mathrm{Ni} / \mathrm{Al}_{2} \mathrm{O}_{3}$ 
catalysts have comparable surface area, the $\mathrm{Ni}^{\circ}$ particle size for the $20 \% \mathrm{Ni} / \mathrm{MgAl}_{2} \mathrm{O}_{4}$ catalyst $(4.6 \mathrm{~nm})$ is nearly half that of the size of the $\mathrm{Ni}^{\circ}$ on the $20 \% \mathrm{Ni} / \mathrm{Al}_{2} \mathrm{O}_{3}$ catalyst $(8.6 \mathrm{~nm}) . \mathrm{Ni}^{\circ}$ particle sizes of the spent catalysts

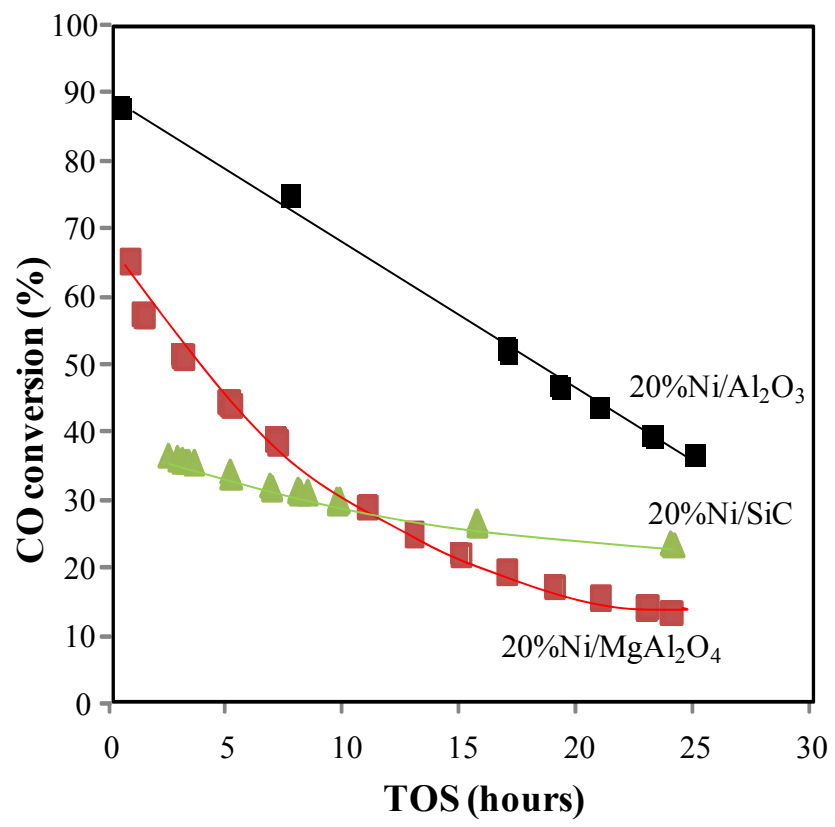

Figure 1.10. CO Conversion as a Function of the Time-On-Stream for CO Methanation Reaction for the $20 \% \mathrm{Ni} / \mathrm{SiC}(\triangle), 20 \% \mathrm{Ni} / \mathrm{Al}_{2} \mathrm{O}_{3}(\boldsymbol{m})$ and $20 \% \mathrm{Ni} / \mathrm{MgAl}_{2} \mathrm{O}_{4}(\square)$ Catalysts (no sorbent) with $\mathrm{T}=500^{\circ} \mathrm{C}$, GHSV $=87000 \mathrm{~h}-1, \mathrm{H}_{2}=48 \%, \mathrm{CO}=48 \%$ and $\mathrm{N}_{2}=4 \%$. Catalyst $=0.1 \mathrm{~g}$ and $\mathrm{SiC}$ diluent $=3.0 \mathrm{~g}$.

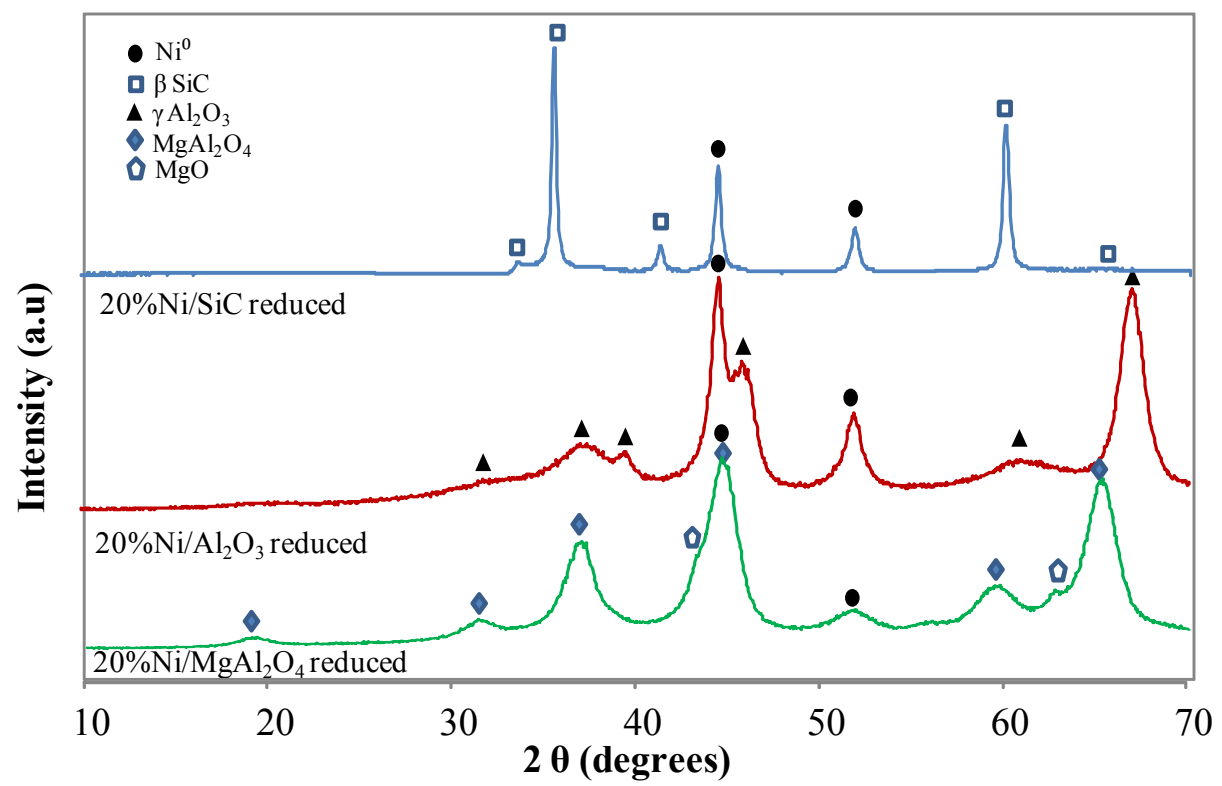

Figure 1.11. XRD Patterns Recorded for the $20 \% \mathrm{Ni} / \mathrm{SiC}, 20 \% \mathrm{Ni} / \mathrm{Al}_{2} \mathrm{O}_{3}$ and $20 \% \mathrm{Ni} / \mathrm{MgAl}_{2} \mathrm{O}_{4}$ Catalysts after Reduction at $600^{\circ} \mathrm{C}$ for $2 \mathrm{hr}$ under $10 \% \mathrm{H}_{2} / \mathrm{N}_{2}$ 


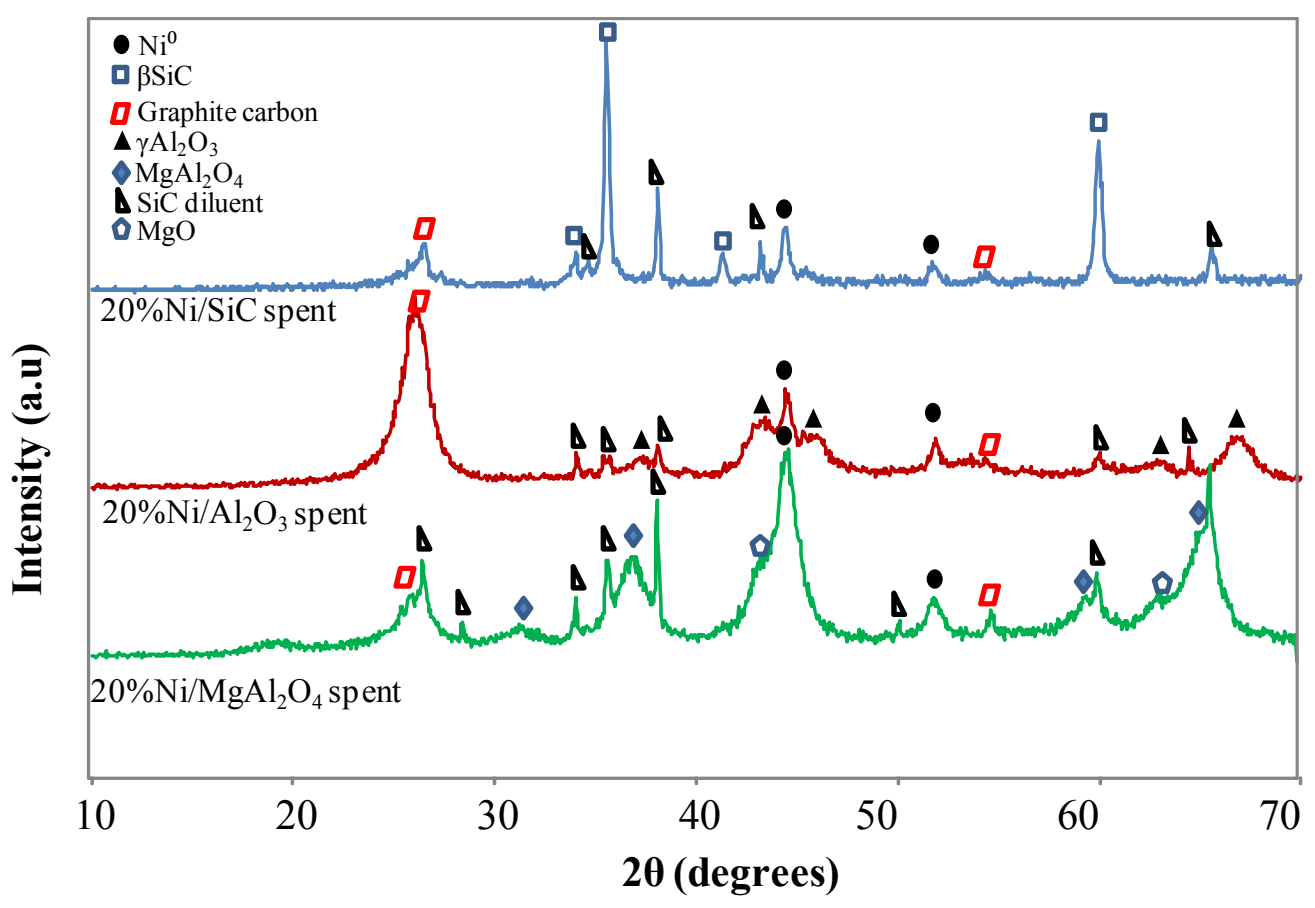

Figure 1.12. XRD Patterns Recorded for the Spent $20 \% \mathrm{Ni} / \mathrm{SiC}, 20 \% \mathrm{Ni} / \mathrm{Al}_{2} \mathrm{O}_{3}$ and $20 \% \mathrm{Ni} / \mathrm{MgAl}_{2} \mathrm{O}_{4}$ Catalysts after the Stability Test for CO Methanation

Table 1.1. BET Surface Area, Ni Particle Sizes and Percentage of Coke Present on the Catalysts after the Stability Test for CO Methanation (no sorbent included).

\begin{tabular}{|c|c|c|c|c|c|}
\hline \multirow[t]{2}{*}{ Catalyst } & \multicolumn{2}{|c|}{ Surface Area $\left(\mathrm{m}^{2} / \mathrm{g}\right)$} & \multicolumn{2}{|c|}{ Ni Particle Size (nm) } & \multirow[t]{2}{*}{ Coke (\%) } \\
\hline & Reduced & Spent $^{\mathrm{a}}$ & Reduced & Spent $^{\mathrm{a}}$ & \\
\hline $20 \% \mathrm{Ni} / \mathrm{SiC}$ & 15 & 90 & 22 & 22 & 25 \\
\hline $20 \% \mathrm{Ni} / \mathrm{Al}_{2} \mathrm{O}_{3}$ & 122 & 121 & 8.6 & 20.6 & 69 \\
\hline $20 \% \mathrm{Ni} / \mathrm{MgAl}_{2} \mathrm{O}_{4}$ & 107 & 109 & 4.6 & 11.2 & 31 \\
\hline
\end{tabular}

(i.e., after the stability test) were calculated from the XRD patterns presented in Figure 1.12 . The $\mathrm{Ni}^{\circ}$ particle size of the spent $20 \% \mathrm{Ni} / \mathrm{SiC}$ sample is $22 \mathrm{~nm}$, same as that of the reduced catalyst. This shows that the $20 \% \mathrm{Ni} / \mathrm{SiC}$ catalyst does not sinter during $\mathrm{CO}$ methanation. Contrary to the $20 \% \mathrm{Ni} / \mathrm{SiC}$ catalyst, both $20 \% \mathrm{Ni} / \mathrm{Al}_{2} \mathrm{O}_{3}$ and $20 \% \mathrm{Ni} / \mathrm{MgAl}_{2} \mathrm{O}_{4}$ suffer from severe $\mathrm{Ni}^{\circ}$ particle sintering during reaction.

Specifically, under the methanation reaction conditions tested, $\mathrm{Ni}^{\circ}$ particles size increased from $8.6 \mathrm{~nm}$ to $20.6 \mathrm{~nm}$, and from $4.6 \mathrm{~nm}$ to $11.2 \mathrm{~nm}$, for the $20 \% \mathrm{Ni} / \mathrm{Al}_{2} \mathrm{O}_{3}$ and $20 \% \mathrm{Ni} / \mathrm{MgAl}_{2} \mathrm{O}_{4}$ catalysts, respectively. Enhanced resistance to $\mathrm{Ni}^{\circ}$ particle sintering is one of the major reasons that $20 \% \mathrm{Ni} / \mathrm{SiC}$ is more stable than $20 \% \mathrm{Ni} / \mathrm{Al}_{2} \mathrm{O}_{3}$ and $20 \% \mathrm{Ni} / \mathrm{MgAl}_{2} \mathrm{O}_{4}$ catalysts. The lower conversion observed for $20 \% \mathrm{Ni} / \mathrm{MgAl}_{2} \mathrm{O}_{4}$, compared to the $20 \% \mathrm{Ni} / \mathrm{Al}_{2} \mathrm{O}_{3}$ presenting a lower $\mathrm{Ni}$ dispersion could be due to a potential structure sensitivity (Rostrup-Nielsen et al. 2007) or to the basic character of the $\mathrm{MgAl}_{2} \mathrm{O}_{4}$ support as well as the incomplete reduction of the nickel. Acid/base properties of the support have been reported to affect the catalytic activity for the $\mathrm{CO}$ methanation and higher $\mathrm{CO}$ methanation activity was observed for acidic 
supports (Kowalczyk et al. 2008, Xin et al. 1986). Peaks characteristic of graphite carbon were also detected for all three catalysts using XRD as shown in Figure 1.12. The amount of coke present on the spent samples was determined using TPO-TGA analysis. The results shown in Table 1.1 provide the evidence of a more significant coke formation on the $20 \% \mathrm{Ni} / \mathrm{Al}_{2} \mathrm{O}_{3}$ catalyst ( $69 \%$ of coke) compared to the $20 \% \mathrm{Ni} / \mathrm{SiC}\left(25 \%\right.$ of coke) and $20 \% \mathrm{Ni} / \mathrm{MgAl}_{2} \mathrm{O}_{4}(31 \%$ of coke) catalysts. The higher amount of coke for $20 \% \mathrm{Ni} / \mathrm{Al}_{2} \mathrm{O}_{3}$ catalyst, compared to $20 \% \mathrm{Ni} / \mathrm{SiC}$ catalyst, cannot be attributed to the presence of smaller Ni particles (i.e., $8.6 \mathrm{~nm}$ vs. $22 \mathrm{~nm}$ for $20 \% \mathrm{Ni} / \mathrm{SiC}$ ) since smaller Ni particles are expected to be more resistant to coke formation (Kim et al. 2000, Christensen et al. 2006, Jeong et al. 2006). Higher coke formation for $\mathrm{Ni} / \mathrm{Al}_{2} \mathrm{O}_{3}$ catalyst is likely due to the surface acidity of $\mathrm{Al}_{2} \mathrm{O}_{3}$. Alkali promoters such as $\mathrm{Mg}$ are well known to act as suppressants to retard carbon deposition on methane steam reforming catalysts (Rostrup-Nielsen 1975). Less coking is thus expected for a $\mathrm{MgAl}_{2} \mathrm{O}_{4}$ supported catalyst or a catalyst based on an inert $\mathrm{SiC}$ support than for an $\mathrm{Al}_{2} \mathrm{O}_{3}$ supported catalyst (Rostrup-Nielsen 1975). We can thus conclude that the deactivation observed for the $20 \% \mathrm{Ni} / \mathrm{Al}_{2} \mathrm{O}_{3}$ and $20 \% \mathrm{Ni} / \mathrm{MgAl}_{2} \mathrm{O}_{4}$ catalysts during the stability test measurement was due to the sintering of $\mathrm{Ni}^{\circ}$ particles as well as coking while coking was the main reason for the deactivation of $20 \% \mathrm{Ni} / \mathrm{SiC}$ catalyst.

The spent $20 \% \mathrm{Ni} / \mathrm{SiC}, 20 \% \mathrm{Ni} / \mathrm{Al}_{2} \mathrm{O}_{3}$ and $20 \% \mathrm{Ni} / \mathrm{MgAl}_{2} \mathrm{O}_{4}$ catalysts were also analyzed using TEM to determine the nature of coke species. Representative TEM images are shown in Figure 1.7. For the spent $20 \% \mathrm{Ni} / \mathrm{Al}_{2} \mathrm{O}_{3}$ and $20 \% \mathrm{Ni} / \mathrm{MgAl}_{2} \mathrm{O}_{4}$ samples, only carbon filaments were observed. For the spent $20 \% \mathrm{Ni} / \mathrm{SiC}$ sample, few carbon filaments were observed with most of the carbon being present in the form of amorphous structures. This has already been observed and attributed to the different interactions between the nickel and the $\mathrm{SiC}$ surface, leading to the formation of peculiar exposed nickel faces that are not facile for growing carbon filaments (Leroi et al. 2004). The presence of amorphous carbon on the spent $20 \% \mathrm{Ni} / \mathrm{SiC}$ also explains the significant increase of its surface area (see Table 1.1).

It is obvious from these results that the $20 \% \mathrm{Ni} / \mathrm{SiC}$ catalyst is more stable than the $20 \% \mathrm{Ni} / \mathrm{Al}_{2} \mathrm{O}_{3}$ and $20 \% \mathrm{Ni} / \mathrm{MgAl}_{2} \mathrm{O}_{4}$ catalysts under conventional $\mathrm{CO}$ methanation reaction conditions due to lower coke formation and less sintering. Hence, the rapid deactivation observed for the $20 \% \mathrm{Ni} / \mathrm{SiC}$ during the cyclic experiments of the integrated test cannot be explained from the stability test results. We have thus analyzed the spent $20 \% \mathrm{Ni} / \mathrm{SiC}$ after the cyclic experiments of the integrated test. The XRD analysis of the spent $20 \% \mathrm{Ni} / \mathrm{SiC}$ sample (after decarbonation and carbonation) revealed the presence of $\mathrm{Ni}_{2} \mathrm{Si}_{\text {alloy }}$ (inset of Figure 1.13). It is likely that the $\mathrm{Ni}_{2} \mathrm{Si}$ alloy was formed during the decarbonation step at $800^{\circ} \mathrm{C}$. Indeed, an in -situ XRD analysis of a $\mathrm{Ni} / \mathrm{SiC}$ film has shown the formation of $\mathrm{Ni}_{2} \mathrm{Si}$ alloy after $4 \mathrm{~min}$ at $799^{\circ} \mathrm{C}$ under $\mathrm{N}_{2}$ (Fujimura and Tanaka 1999). According to a study by Imamura and Wallace (2012), the activity of $\mathrm{Ni}_{2} \mathrm{Si}$ alloy is lower than that of $\mathrm{Ni}^{\circ}$ particles for $\mathrm{CO}$ methanation reaction. The formation of $\mathrm{Ni}_{2} \mathrm{Si}$ alloy present on the $20 \% \mathrm{Ni} / \mathrm{SiC}$ catalyst could thus be responsible for its deactivation. In addition, the Ni particle size of the spent sample, as determined from the XRD pattern in Figure 1.13 also increased to $36 \mathrm{~nm}$ compared to that of the reduced catalyst (i.e., $22 \mathrm{~nm}$ ). This indicates that the Ni particles sinter during the decarbonation step which also contributes to catalyst deactivation. Therefore, the deactivation of $20 \% \mathrm{Ni} / \mathrm{SiC}$ catalyst under the carbonation/decarbonation conditions was due to both sintering of the $\mathrm{Ni}$ particles and transformation of the Ni particles to $\mathrm{Ni}_{2} \mathrm{Si}$ alloy during decarbonation. 


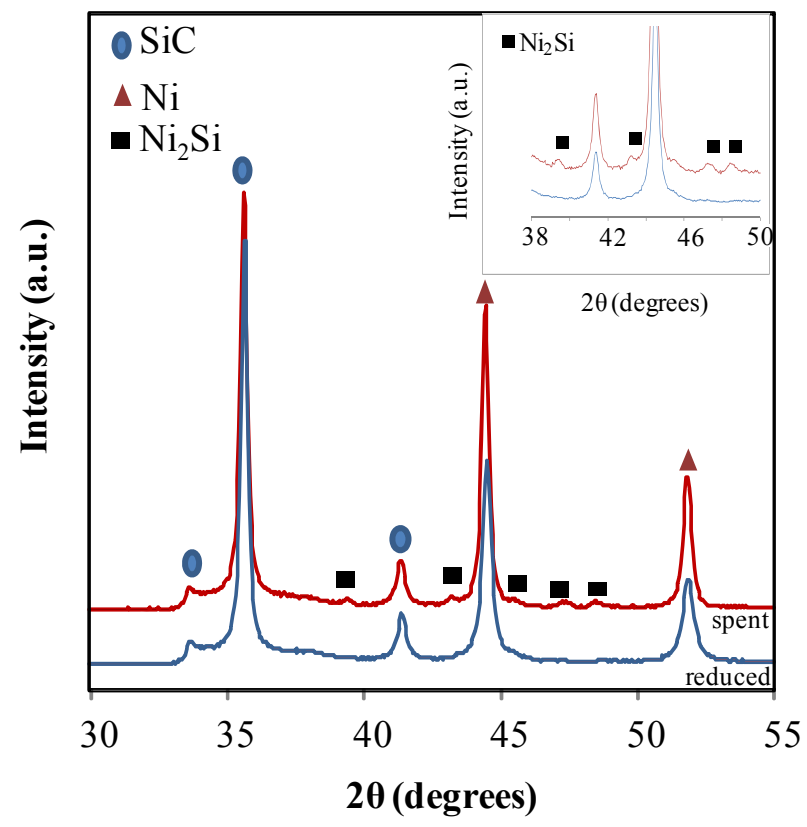

Figure 1.13. XRD Patterns of the Reduced $20 \% \mathrm{Ni} / \mathrm{SiC}$ Catalyst and the Spent $20 \% \mathrm{Ni} / \mathrm{SiC}$ Sample after Two Carbonation/Decarbonation Cycles

Both $20 \% \mathrm{Ni} / \mathrm{Al}_{2} \mathrm{O}_{3}$ and $20 \% \mathrm{Ni} / \mathrm{MgAl}_{2} \mathrm{O}_{4}$ suffer from rapid deactivation under the conventional $\mathrm{CO}$ methanation reaction conditions due to sintering and coking. However, the $20 \% \mathrm{Ni} / \mathrm{Al}_{2} \mathrm{O}_{3}$ deactivated more quickly than the $20 \% \mathrm{Ni} / \mathrm{MgAl}_{2} \mathrm{O}_{4}$ during the cyclic experiments, with $\mathrm{CO}_{2}$ sorption and with steam addition (Figure 1.8 and Figure 1.9). We have thus characterized the spent $20 \% \mathrm{Ni} / \mathrm{Al}_{2} \mathrm{O}_{3}$ and $20 \%$ $\mathrm{Ni} / \mathrm{MgAl}_{2} \mathrm{O}_{4}$ after the cyclic experiments of the integrated test using XRD, and the results are shown in Figure 1.14. One can see that the peaks characteristic of the supports are sharper by comparison with the patterns recorded for the reduced catalysts. These results indicate that the degree of crystallization of the $\mathrm{Al}_{2} \mathrm{O}_{3}$ and $\mathrm{MgAl}_{2} \mathrm{O}_{4}$ supports increased after the multiple carbonation/decarbonation cycles. The high decarbonation temperature (i.e., $800^{\circ} \mathrm{C}$ ) is likely responsible for the crystallization of the supports. In addition, high decarbonation temperature also caused the sintering of $\mathrm{Ni}^{\circ}$ particles. $\mathrm{The}^{\mathrm{Ni}}{ }^{\circ}$ particle size of the spent $20 \% \mathrm{Ni} / \mathrm{MgAl}_{2} \mathrm{O}_{4}$ increased to $14 \mathrm{~nm}$ from $6.8 \mathrm{~nm}$ after reduction at $600^{\circ} \mathrm{C}$ followed by treatment under $\mathrm{N}_{2}$ at $800^{\circ} \mathrm{C}$ for $1 \mathrm{hr}$. The $\mathrm{Ni}^{\circ}$ particles size is thus twice higher after $20 \mathrm{hrs}$ on-stream. For the $20 \% \mathrm{Ni} / \mathrm{Al}_{2} \mathrm{O}_{3}$, under the same conditions the $\mathrm{Ni}^{\circ}$ particles size increased from $10.5 \mathrm{~nm}$ to $16 \mathrm{~nm}$. The $\mathrm{Ni}^{\circ}$ particles are thus 1.5 times bigger after only $8 \mathrm{hrs}$ on-stream. We can deduce from these results that the sintering rate is higher for the $20 \% \mathrm{Ni} / \mathrm{Al}_{2} \mathrm{O}_{3}$ catalyst during the cyclic experiments. It is also worth noting that coking is more severe for the $20 \% \mathrm{Ni} / \mathrm{Al}_{2} \mathrm{O}_{3}$ catalyst than for the $20 \% \mathrm{Ni} / \mathrm{MgAl}_{2} \mathrm{O}_{4}$ catalyst, as explained above, due to the surface acidity (Rostrup-Nielsen 1975). Hence, the rapid deactivation observed for the $20 \% \mathrm{Ni} / \mathrm{Al}_{2} \mathrm{O}_{3}$ compared to the $20 \% \mathrm{Ni} / \mathrm{MgAl}_{2} \mathrm{O}_{4}$ is likely due to higher coking and sintering rate compared to the $20 \% \mathrm{Ni} / \mathrm{MgAl}_{2} \mathrm{O}_{4}$. 


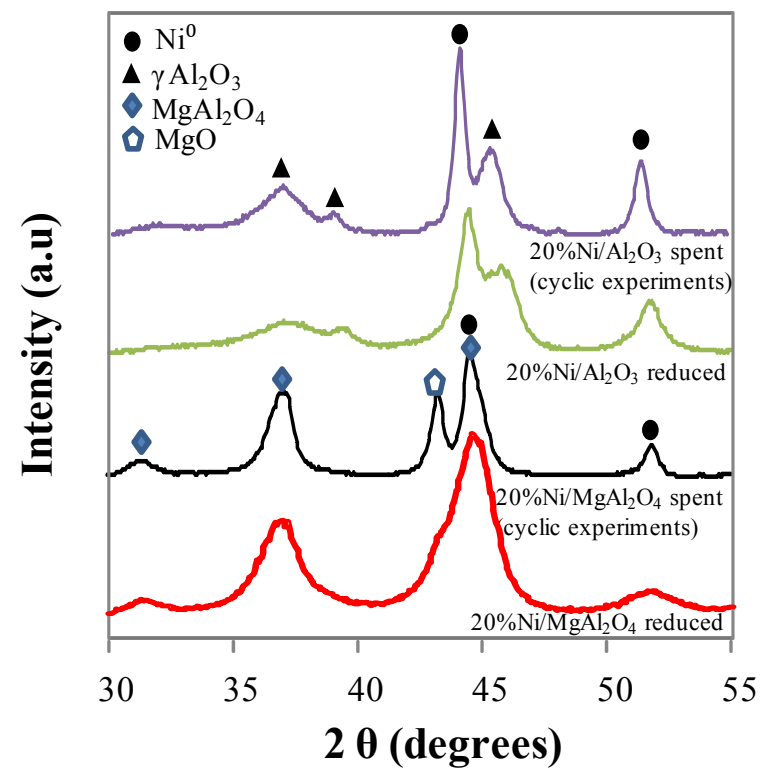

Figure 1.14. $\mathrm{XRD}$ Patterns of for the Reduced $20 \% \mathrm{Ni} / \mathrm{Al}_{2} \mathrm{O}_{3}$ and $20 \% \mathrm{Ni} / \mathrm{MgAl}_{2} \mathrm{O}_{4}$ Catalysts and for the Spent $20 \% \mathrm{Ni} / \mathrm{Al}_{2} \mathrm{O}_{3}$ and $20 \% \mathrm{Ni} / \mathrm{MgAl}_{2} \mathrm{O}_{4}$ Samples after Multiple Carbonation/Decarbonation Cycles

\subsubsection{Syngas-to-Hydrocarbon Fuels through Higher Alcohol Intermediates}

\subsubsection{One-Step Conversion of Syngas to Fuels}

\section{Catalytic Performance of the Methanol Synthesis Catalyst}

In a previous study, we described a $\mathrm{Pd} / \mathrm{ZnO} / \mathrm{Al}_{2} \mathrm{O}_{3}$ catalyst that efficiently produces methanol and dimethyl ether (DME) at temperatures up to $400^{\circ} \mathrm{C}$ with excellent stability relative to a commercial $\mathrm{Cu}$-based methanol catalyst (Lebarbier et al. 2012). We have thus chosen to determine the performance of the $5 \mathrm{Pd} / \mathrm{ZnO} / \mathrm{Al}_{2} \mathrm{O}_{3}$ methanol synthesis catalyst physically mixed with HZSM-5 for the one-step conversion of syngas to hydrocarbons at $300^{\circ} \mathrm{C}, 70 \mathrm{bars}$, and a GHSV $=700 \mathrm{~h}^{-1}$. The results presented in Table 1.2 show that the CO conversion is equal to $45 \%$ and the hydrocarbons selectivity is equal to $54.7 \%$. The hydrocarbons selectivity is lower than that of the HAS catalysts (see next section) because of the high reactivity of the catalyst for the WGS reaction (Dagle et al. 2008). Indeed, the $\mathrm{CO}_{2}$ selectivity is high and equal to $45.3 \%$. Note that the $\mathrm{C}_{5}{ }^{+}$hydrocarbons represent $41.3 \%$ of the hydrocarbons product. However, half of the $\mathrm{C}_{5}{ }^{+}$fraction consists of unwanted durene. Durene is an undesirable component of gasoline because of its high melting point $\left(79^{\circ} \mathrm{C}\right)$ and its tendency to crystallize out of solution at temperatures below $79^{\circ} \mathrm{C}$ (Chang et al. 1977). 
Table 1.2. One-Step Conversion of Syngas to Fuels. CO conversion, products selectivity and hydrocarbons product distribution of the alcohols synthesis catalysts mixed with HZSM-5. $\mathrm{T}=300^{\circ} \mathrm{C}, \mathrm{P}=70$ bars, GHSV $=700 \mathrm{~h}-1$, zeolite: alcohol synthesis catalyst ratio $=3: 1$ by wt.

\begin{tabular}{|c|c|c|c|c|c|c|c|c|c|}
\hline \multirow[t]{2}{*}{ Catalysts Mixture } & \multirow[t]{2}{*}{$\begin{array}{c}\text { CO Conversion }^{\mathrm{a}} \\
(\%)\end{array}$} & \multicolumn{3}{|c|}{$\begin{array}{c}\text { Selectivity } \\
(\%)\end{array}$} & \multicolumn{3}{|c|}{$\begin{array}{c}\text { Hydrocarbons Product } \\
\text { Distribution } \\
(\%) \\
\end{array}$} & \multirow[t]{2}{*}{$\begin{array}{l}\mathrm{C}_{5}^{+} \\
\text {Yield } \\
(\%)\end{array}$} & \multirow{2}{*}{$\begin{array}{c}\text { Durene } \\
\text { Content in } \\
\mathrm{C}_{5}^{+} \text {Fraction } \\
(\%)\end{array}$} \\
\hline & & Hydrocarbons & $\mathrm{CO}_{2}$ & Oxygenates $^{\mathrm{b}}$ & $\mathrm{C}_{1}$ & $\mathrm{C}_{2}-\mathrm{C}_{4}$ & $\mathrm{C}_{5}^{+}$ & & \\
\hline $5 \mathrm{Pd} / \mathrm{ZnO} / \mathrm{Al}_{2} \mathrm{O}_{3}+\mathrm{HZSM}-5$ & 45.0 & 54.7 & 45.3 & - & 9.3 & 49.4 & 41.3 & 10.2 & 48 \\
\hline $15 \mathrm{Co} 1 \mathrm{Zr} 0.5 \mathrm{La} / \mathrm{AC}+\mathrm{HZSM}-5$ & 28.0 & 86.4 & 11.7 & 1.9 & 56.2 & 17.6 & 26.2 & 6.3 & 3.2 \\
\hline $5 \mathrm{Rh} 2.5 \mathrm{Mn} / \mathrm{SiO}_{2}+\mathrm{HZSM}-5$ & 44.0 & 56 & 2.5 & 41.5 & 74.6 & 23.6 & 1.8 & 0.4 & - \\
\hline 5Rh2.5Mn/MWCNT + HZSM-5 & 47.6 & 74 & 16.0 & 10.0 & 55.8 & 23.1 & 21.1 & 7.4 & 2.3 \\
\hline $\mathrm{Co}_{3} \mathrm{Cu}_{1}-11 \% \mathrm{MWCNT}+\mathrm{HZSM}-5$ & 45.0 & 76.7 & 23.0 & 0.3 & 35.0 & 32.0 & 33.0 & 11.4 & 2.7 \\
\hline $0.5 \mathrm{Pd} / \mathrm{FeCoCu}+\mathrm{HZSM}-5$ & 50.0 & 61.8 & 38.0 & 0.2 & 29.7 & 31.5 & 38.8 & 12.0 & 1.0 \\
\hline $\mathrm{FeCoCu}+\mathrm{HZSM}-5$ & 40.6 & 63.6 & 35.9 & 0.5 & 48.4 & 37.1 & 14.5 & 3.7 & - \\
\hline
\end{tabular}

\section{Catalytic Performance of the Higher Alcohols Synthesis Catalysts}

The performance of the higher alcohol synthesis (HAS) catalysts physically mixed with HZSM-5 was evaluated under the same conditions as for the methanol synthesis catalyst and the results are presented in Table 1.2 as well. For all the catalysts mixtures, the $\mathrm{CO}$ conversion is similar and between $40-50 \%$, except for $15 \mathrm{Co} 1 \mathrm{Zr} 0.5 \mathrm{La} / \mathrm{AC}$. A lower conversion equal to $28 \%$ was observed for the $15 \mathrm{Co} 1 \mathrm{Zr} 0.5 \mathrm{La} / \mathrm{AC}$ catalyst. Among the HAS catalysts, the $5 \mathrm{Rh} 2.5 \mathrm{Mn} / \mathrm{SiO}_{2}$ and $5 \mathrm{Rh} 2.5 \mathrm{Mn} / \mathrm{MWCNT}$ catalysts distinguish themselves from the others. The selectivity toward the oxygenated compounds with the supported Rh catalysts is quite high and equal to $41.4 \%$ and $10.0 \%$, respectively. The Rh catalysts are known to be very active for the conversion of syngas into oxygenates (i.e., alcohols, acids, ketones, esters) (Hu et al. 2007, Gerber et al. 2007). However, a large fraction of theses oxygenates consists of species such as acetic acid and acetaldehyde that are not easily converted into hydrocarbons over HZSM-5 under the present reaction conditions. For the HZSM-5 $+15 \mathrm{Co} 1 \mathrm{Zr} 0.5 \mathrm{La} / \mathrm{AC}$ mixture, a high selectivity toward hydrocarbons is observed (i.e., 86.5\%). However, undesired methane is the main hydrocarbon product and the yield toward the preferred $\mathrm{C}_{5}{ }^{+}$hydrocarbons is quite low and equal to $6.3 \%$. Among the different HAS catalysts, the highest $\mathrm{C}_{5}{ }^{+}$yield and lowest methane formation is observed for the combination HZSM$5+0.5 \mathrm{Pd} / \mathrm{FeCoCu}$ mixture. In addition, as shown in Figure 1.15, the conversion is fairly stable with TOS for the $\mathrm{HZSM}-5+0.5 \mathrm{Pd} / \mathrm{FeCoCu}$ mixture. The yield toward the $\mathrm{C}_{5}{ }^{+}$hydrocarbons is quite comparable with the $5 \mathrm{Pd} / \mathrm{ZnO} / \mathrm{Al}_{2} \mathrm{O}_{3}$ methanol synthesis catalyst (yield $=10.2 \%$ ) and with the $0.5 \mathrm{Pd} / \mathrm{FeCoCu} \mathrm{HAS}$ catalyst (yield $=11.9 \%$ ). However, as explained earlier, for the methanol synthesis catalyst unwanted durene represents half of the $\mathrm{C}_{5}{ }^{+}$fraction. On the contrary, the production of durene is negligible with any HAS catalyst and it is only $\sim 1 \%$ of the $\mathrm{C}_{5}{ }^{+}$hydrocarbons product for the $0.5 \mathrm{Pd} / \mathrm{FeCoCu}$ catalyst. Note that these results suggest that durene is produced via benzene alkylation with methyl species from methanol. The production of desired $\mathrm{C}_{5}^{+}$gasoline type hydrocarbons is thus higher with the $0.5 \mathrm{Pd} / \mathrm{FeCoCu}$ catalyst and it appears as the most promising candidate for the one-step conversion of syngas to fuels. These preliminary findings encouraged us to investigate further the HZSM- 
$5+0.5 \mathrm{Pd} / \mathrm{FeCoCu}$ combination and determine the effect of processing parameters such as temperature, pressure, GHSV, and the HZSM-5:0.5Pd/FeCoCu weight ratio.

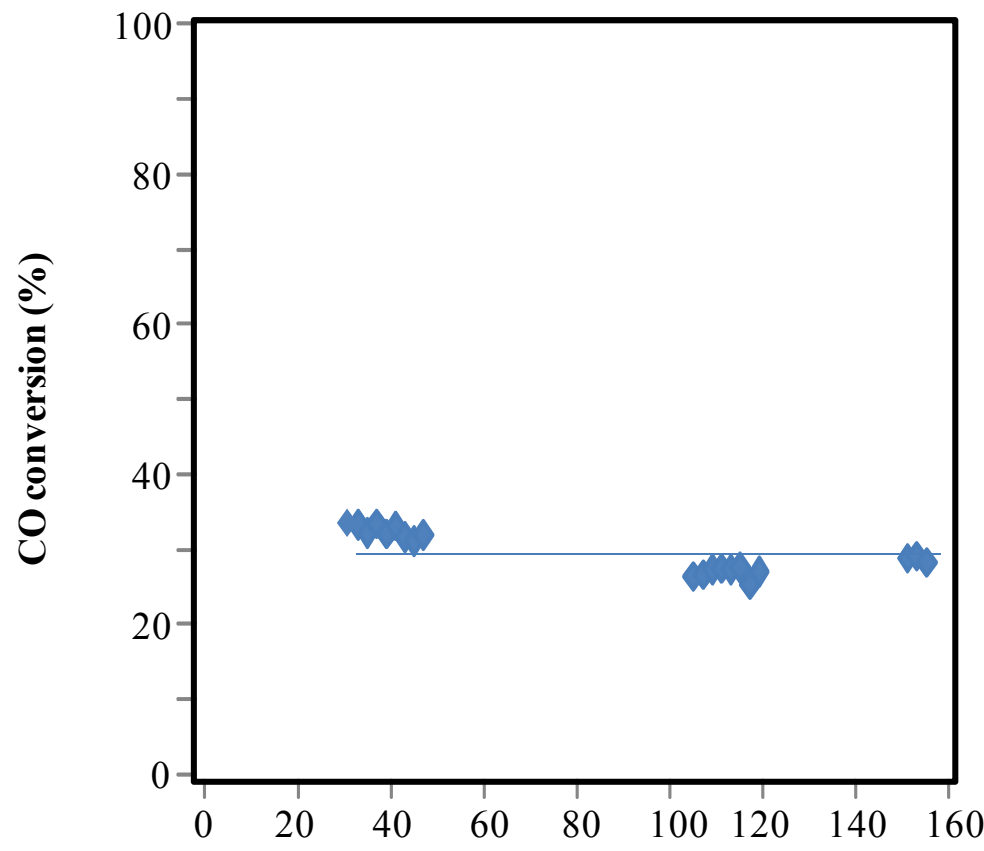

Time on stream (hours)

Figure 1.15. CO Conversion as a Function of TOS for the HZSM- $5+0.5 \mathrm{Pd} / \mathrm{FeCuCo}$ Mixture; $\mathrm{H}_{2} / \mathrm{CO}=1$, $\mathrm{T}=300^{\circ} \mathrm{C}, \mathrm{P}=70$ bars, GHSV $=3000 \mathrm{hr}^{-1}, \mathrm{HZSM}-5: 0.5 \mathrm{Pd} / \mathrm{FeCuCo}$ ratio is $3: 1$ by Weight

$\underline{\text { Reactivity of the HZSM- } 5+0.5 \mathrm{Pd} / \mathrm{FeCoCu} \text { Catalyst Mixture: Effect of Operating Conditions }}$

The catalytic performance of the HZSM- $5+0.5 \mathrm{Pd} / \mathrm{FeCoCu}$ mixture was determined for temperatures between $300-370^{\circ} \mathrm{C}$ at 70 bars, $\mathrm{HZSM}-5: 0.5 \mathrm{Pd} / \mathrm{FeCoCu}$ catalysts ratio $=3: 1$ and $\mathrm{GHSV}=3000 \mathrm{~h}^{-1}$. As illustrated in Figure 1.16, the CO conversion increases from $\sim 36 \%$ to $87 \%$ when the temperature increases from 300 to $350^{\circ} \mathrm{C}$. When the temperature was increased from $350^{\circ} \mathrm{C}$ to $370^{\circ} \mathrm{C}$, thermodynamic constraints for the methanol synthesis portion of the reaction scheme likely inhibit further $\mathrm{CO}$ conversion. Note that the higher alcohols formation from syngas is not an equilibrium limited reaction but the $0.5 \mathrm{Pd} / \mathrm{FeCoCu}$ catalyst produces mainly methanol, as shown in Figure 1.17, and syngas-to-methanol conversion is an equilibrium limited reaction. The methane formation increases significantly from $\sim 26 \%$ to $59 \%$ due to increase $\mathrm{CO}$ methanation activity. As for methane, $\mathrm{CO}_{2}$ selectivity increases with the temperature and it is attributed to increase of WGS activity. The oxygenates selectivity is negligible within the range of temperature studied. It indicates that the HZSM-5 converts efficiently the oxygenated compounds into hydrocarbons over the range of temperatures studied, even at low temperature (i.e., $300^{\circ} \mathrm{C}$ ). One could have expected the HZSM-5 to be less active at temperature equal to $300^{\circ} \mathrm{C}$ since the methanol-to-gasoline process is typically conducted at 350 to $400^{\circ} \mathrm{C}$ (Mokrani and Scurrell 2009). Although the hydrocarbons product selectivity decreases only from $\sim 68 \%$ to $54 \%$ when the temperature increases from $300^{\circ} \mathrm{C}$ to $370^{\circ} \mathrm{C}$, the diminution of the $\mathrm{C}_{5}{ }^{+}$hydrocarbon fraction is quite drastic. Indeed, as shown in Table 1.3, the $\mathrm{C}_{5}{ }^{+}$fraction decreases from $\sim 49 \%$ to $15 \%$ when the temperature increases from $300^{\circ} \mathrm{C}$ to $370^{\circ} \mathrm{C}$. These results highlight the importance of operating at lower temperature (i.e., $300^{\circ} \mathrm{C}$ ) to obtain higher yield of $\mathrm{C}_{5}{ }^{+}$hydrocarbons. 


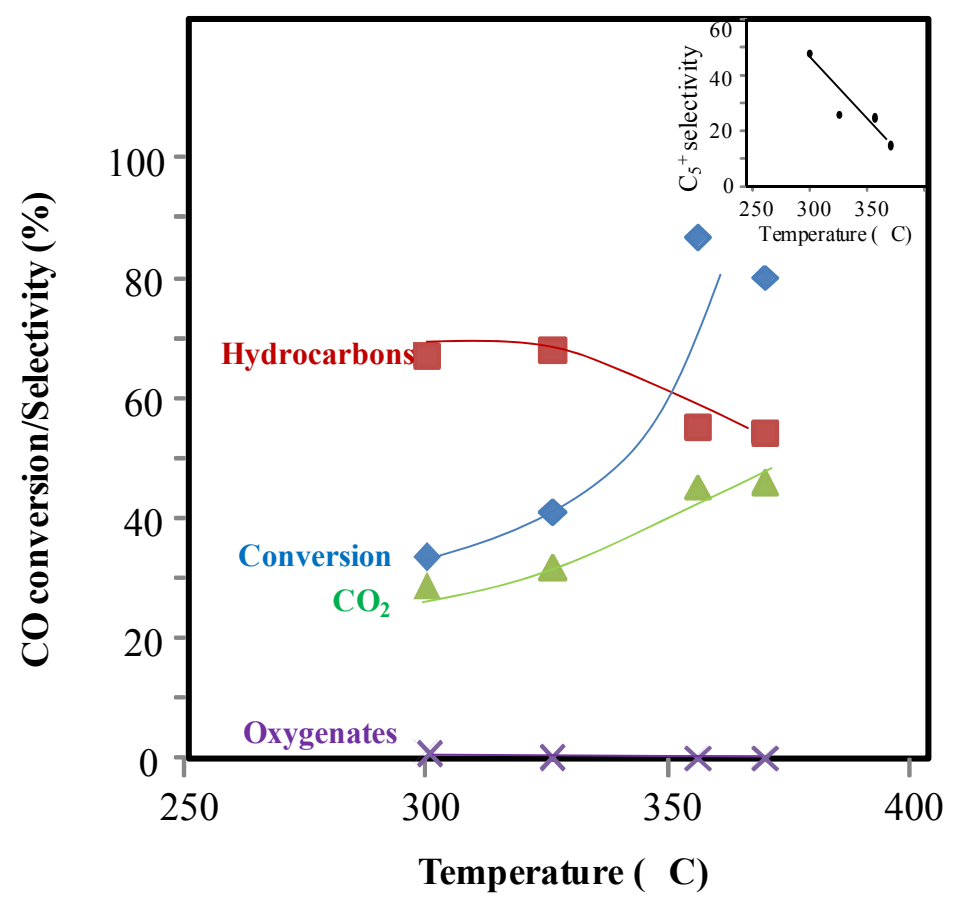

Figure 1.16. CO Conversion and Selectivities as a Function of the Temperature for the HZSM-5+0.5Pd/FeCuCo Mixture; $\mathrm{H}_{2} / \mathrm{CO}=1, \mathrm{P}=70$ bars, GHSV $=3000 \mathrm{hr}-1$, HZSM-5:0.5Pd/FeCoCu ratio $=3: 1$ by weight. Inset: $\mathrm{C} 5+$ selectivity among the hydrocarbons product as a function of the temperature under same reaction conditions.

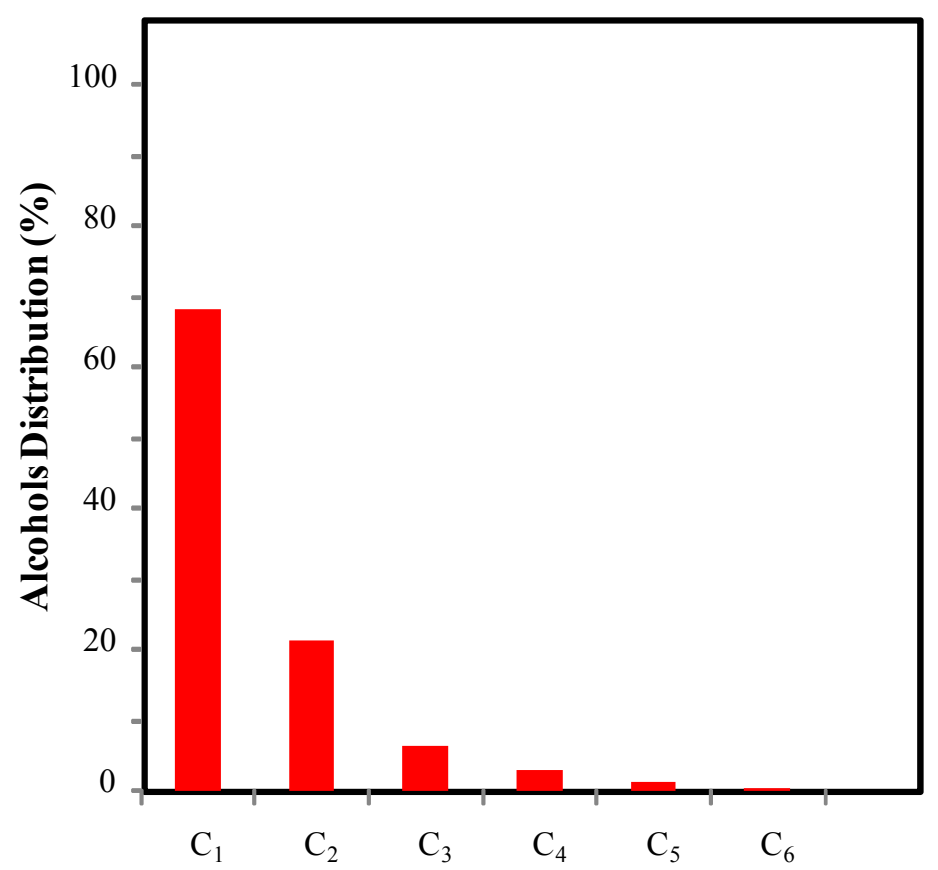

Figure 1.17. Alcohol Product Distribution for Conversion of Syngas to Alcohols over $0.5 \mathrm{Pd} / \mathrm{FeCoCu}$ catalyst $\left(\mathrm{H}_{2} / \mathrm{CO}=1, \mathrm{~T}=300^{\circ} \mathrm{C}, \mathrm{P}=70\right.$ bars, $\left.\mathrm{GHSV}=3000 \mathrm{~h}^{-1}\right)$ 
The catalytic performance of the HZSM-5 $+0.5 \mathrm{Pd} / \mathrm{FeCoCu}$ mixture was then determined for $\mathrm{T}=300^{\circ} \mathrm{C}$, GHSV $=3000 \mathrm{~h}^{-1}, \mathrm{HZSM}-5: 0.5 \mathrm{Pd} / \mathrm{FeCoCu}$ catalysts ratio of $3: 1$ and operating pressures of 20, 45 and 70 bars. As shown in Figure 1.18, with increasing the reaction pressure from 20 to 70 bars the conversion increases from 18 to $36 \%$. Because HAS is favored at high pressure over $1 \% \mathrm{Pd} / \mathrm{FeCoCu}$ catalysts (Yang et al. 2011), the one-step conversion of syngas to hydrocarbons is expected to increase with reaction pressure. A selectivity variation can also be observed with increasing pressure. Indeed, increasing pressure from 20 bars to 70 bars resulted in an increased $\mathrm{CO}_{2}$ selectivity from $19.5 \%$ to $31 \%$ and decreased hydrocarbons selectivity from 80.5 to $\sim 68 \%$. However, as displayed in the inset of Figure 1.18 operating at higher pressure is preferred since the $\mathrm{C}_{5}{ }^{+}$hydrocarbons fraction increases with the increase of pressure. Note that this is in agreement with methanol-to-gasoline process studies from Chang et al. (1978) who showed that the $\mathrm{C}_{5}{ }^{+}$selectivity increases from $66.7 \%$ to $79.7 \%$ when the pressure increases from 1 bar to 50 bars. As shown in Table 1.3, the oxygenated compounds selectivity is minor and below $1 \%$ for any pressure between 20 to 70 bars. This was expected since methanol-to-gasoline process is typically conducted at 26 bars (Keil 1999).

Figure 1.19 presents the catalytic performance results obtained while operating at $300^{\circ} \mathrm{C}, 70$ bars HZSM-5: $0.5 \mathrm{Pd} / \mathrm{FeCoCu}=3: 1$ and GHSV $=700,3000,5650$, and 10,000 $\mathrm{hr}^{-1}$. As anticipated, there is a decrease of CO conversion from $50 \%$ to $20 \%$ when the GHSV increases from $700 \mathrm{~h}^{-1}$ to $10,000 \mathrm{~h}^{-1}$. The hydrocarbons selectivity increased from $\sim 62 \%$ to $73 \%$ while the $\mathrm{CO}_{2}$ selectivity decreases from $38 \%$ to $27 \%$ when the GHSV increases from $700 \mathrm{~h}^{-1}$ to $10,000 \mathrm{hr}^{-1}$. From Table 1.3, one can see that both oxygenates selectivity and $\mathrm{C}_{5}{ }^{+}$hydrocarbons product fraction show little variability when changing the GHSV. Because the CO conversion increases at low GHSV and the $\mathrm{C}_{5}^{+}$hydrocarbons product fraction is not significantly affected by the GHSV, conducting the one-step process at lower GHSV leads to higher $\mathrm{C}_{5}^{+}$yield.

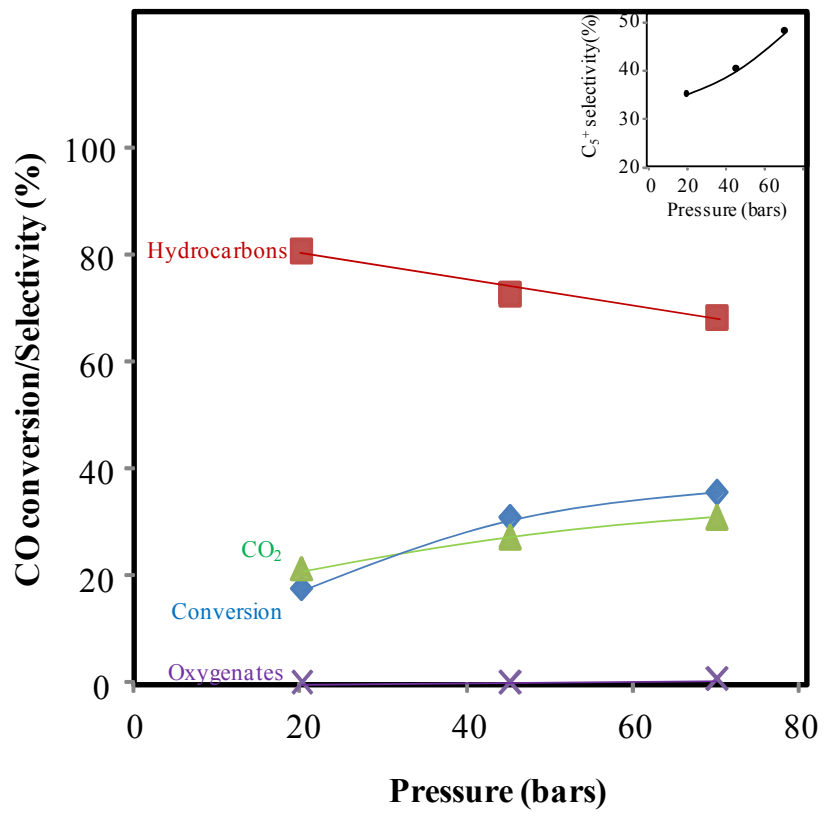

Figure 1.18. CO Conversion and Selectivities as a Function of Pressure for the HZSM-5+0.5Pd/FeCuCo Mixture $\left(\mathrm{H}_{2} / \mathrm{CO}=1, \mathrm{~T}=300^{\circ} \mathrm{C}\right.$, GHSV $=3000 \mathrm{hr}-1, \mathrm{HZSM}-5: 0.5 \mathrm{Pd} / \mathrm{FeCoCu}$ ratio $=3: 1$ by weight). Inset: $\mathrm{C} 5+$ selectivity among the hydrocarbons product fraction as a function of the pressure under same reaction conditions. 
Table 1.3. Effect of Reaction Parameters (i.e., GHSV, temperature, pressure and HZSM-5: 0.5Pd/FeCoCu weight ratio) on CO Conversion, Selectivities, Hydrocarbon Distribution, and C5+ Yield for the HZSM-5:0.5Pd/FeCoCu Mixture and Reactivity of the $0.5 \mathrm{Pd} / \mathrm{FeCoCu}$ HAS Catalysts without HZSM-5 Addition

\begin{tabular}{|c|c|c|c|c|c|c|c|c|c|c|c|}
\hline \multirow[t]{2}{*}{$\begin{array}{l}\text { GHSV } \\
\text { (h-1) }\end{array}$} & \multirow[t]{2}{*}{$\begin{array}{c}\text { Temperature } \\
\left({ }^{\circ} \mathrm{C}\right)\end{array}$} & \multirow[t]{2}{*}{$\begin{array}{l}\text { Pressure } \\
\text { (bars) }\end{array}$} & \multirow{2}{*}{$\begin{array}{c}\text { HZSM-5: } \\
0.5 \mathrm{Pd} / \mathrm{FeCoCu} \\
\text { ratio (weight) }\end{array}$} & \multirow{2}{*}{$\begin{array}{c}\mathrm{CO} \\
\text { conversion }^{\mathrm{a}} \\
(\%)\end{array}$} & \multicolumn{3}{|c|}{ Selectivity (\%) } & \multicolumn{3}{|c|}{$\begin{array}{l}\text { Hydrocarbons product } \\
\text { distribution (\%) }\end{array}$} & \multirow[t]{2}{*}{$\begin{array}{c}\mathrm{C}_{5}^{+} \text {Yield } \\
(\%)\end{array}$} \\
\hline & & & & & Hydrocarbons & $\mathrm{CO}_{2}$ & Oxygenates & $\mathrm{CH}_{4}$ & $\mathrm{C}_{2}-\mathrm{C}_{4}$ & $\mathrm{C}_{5}^{+}$ & \\
\hline 700 & 300 & 70 & $3: 1$ & 50.0 & 61.8 & 38.0 & 0.2 & 29.7 & 31.5 & 38.8 & 12.0 \\
\hline 3,000 & 300 & 70 & $3: 1$ & 35.6 & 68.1 & 31.0 & 0.9 & 26.0 & 25.5 & 48.5 & 11.8 \\
\hline 5,600 & 300 & 70 & $3: 1$ & 28.0 & 70.1 & 29.7 & 0.2 & 28.6 & 33.0 & 38.4 & 7.5 \\
\hline 10,000 & 300 & 70 & $3: 1$ & 20.0 & 73.2 & 26.7 & 0.1 & 28.5 & 35.6 & 35.9 & 5.3 \\
\hline 3,000 & 325 & 70 & $3: 1$ & 41.0 & 68 & 31.8 & 0.1 & 41.4 & 32.6 & 26.1 & 7.3 \\
\hline 3,000 & 350 & 70 & $3: 1$ & 86.7 & 55 & 45.0 & 0.0 & 50.0 & 25.0 & 24.7 & 11.8 \\
\hline 3,000 & 370 & 70 & $3: 1$ & 80.0 & 54.1 & 45.9 & 0.0 & 58.6 & 26.8 & 14.7 & 6.3 \\
\hline 3,000 & 300 & 20 & $3: 1$ & 18.0 & 80.5 & 19.5 & 0.1 & 28.6 & 36.1 & 35.3 & 5.1 \\
\hline 3,000 & 300 & 45 & $3: 1$ & 31.0 & 72.6 & 27.2 & 0.2 & 39.3 & 20.0 & 40.6 & 9.1 \\
\hline 3,000 & 300 & 70 & $1: 1$ & 30.0 & 72.5 & 27.1 & 0.4 & 36.7 & 36.1 & 27.2 & 2.9 \\
\hline 3,000 & 300 & 70 & $1: 3$ & 38.0 & 73.8 & 25.5 & 0.7 & 33.9 & 33.5 & 32.6 & 9.1 \\
\hline $3,000^{\mathrm{b}}$ & 300 & 70 & $0: 1$ & 16.5 & 57.7 & 13 & 29.3 & 53.9 & 41.8 & 4.3 & 0.4 \\
\hline
\end{tabular}

a Data recorded after 50 hrs on-stream.

b Same syngas flowrate and same amount of 0.5Pd/FeCoCu catalyst as for HZSM-5; 0.5Pd/FeCoCu weight ratio is 3:1. 


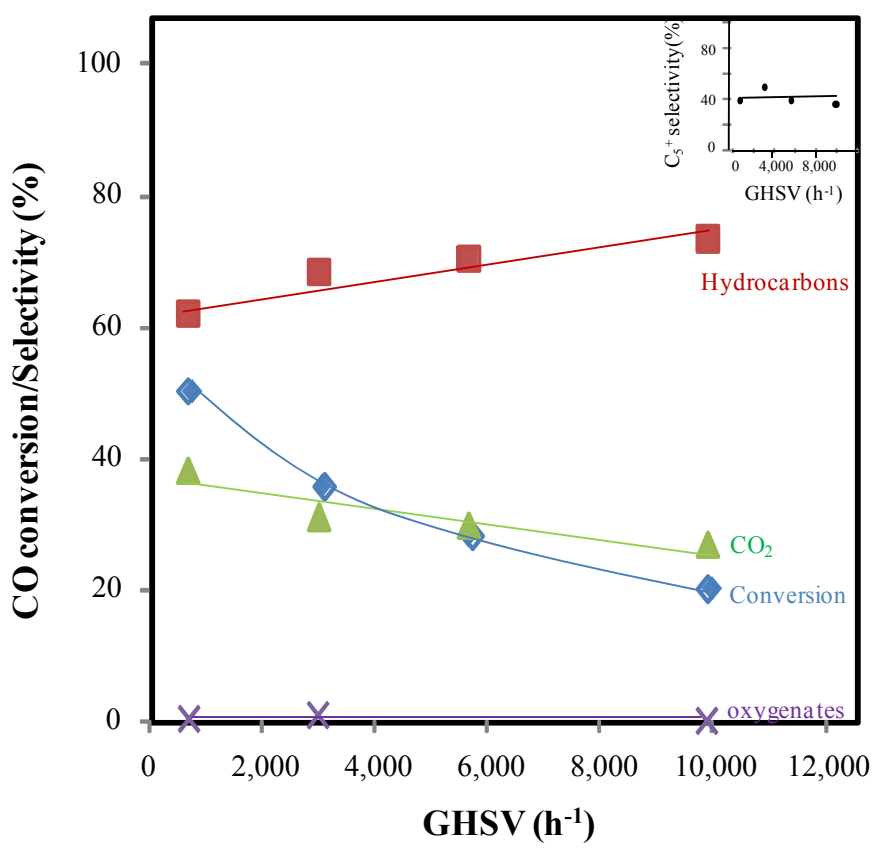

Figure 1.19. CO Conversion and Selectivities as a Function of the GHSV for HZSM-5 $+0.5 \mathrm{Pd} / \mathrm{FeCuCo}$ Mixture $\left(\mathrm{H}_{2} / \mathrm{CO}=1, \mathrm{~T}=300^{\circ} \mathrm{C}, \mathrm{P}=70\right.$ bar, HZSM-5:0.5Pd/FeCoCu ratio $=3: 1$ by weight $)$. Inset: $\mathrm{C} 5+$ selectivity among the hydrocarbons product fraction as a function of the GHSV under same reaction conditions.

The results reported in the sections above were all conducted with a HZSM-5: $0.5 \mathrm{Pd} / \mathrm{FeCoCu}$ ratio of 3:1 by weight. For these experiments, the oxygenated compounds selectivity was negligible indicating that there was a sufficient amount of HZSM-5 to convert the alcohols synthesized from syngas. These results suggested to us that it might be possible to lower the HZSM-5: 0.5Pd/FeCoCu ratio (i.e., lower the amount of HZSM-5) while keeping the same catalytic performance. To determine the impact of the HZSM-5: $0.5 \mathrm{Pd} / \mathrm{FeCoCu}$ ratio on the reactivity two additional experiments were thus conducted at $300^{\circ} \mathrm{C}$, 70 bars, GHSV $=3000 \mathrm{~h}^{-1}$, and HZSM-5: $0.5 \mathrm{Pd} / \mathrm{FeCoCu}$ ratio equal to $1: 1$ and $1: 3$. The results displayed Figure 1.20 clearly show similar conversion and selectivity for the three HZSM-5:0.5Pd/FeCoCu ratios. However, one can see from the inset of Figure 1.20 that the $\mathrm{C}_{5}{ }^{+}$fraction of the hydrocarbons product increases with the HZSM-5: $0.5 \mathrm{Pd} / \mathrm{FeCoCu}$ ratio. In addition, detailed analysis of the $\mathrm{C}_{5}^{+}$fraction indicated that the amount of aromatic compounds increases with the HZSM-5: $0.5 \mathrm{Pd} / \mathrm{FeCoCu}$ ratio from $29.2 \%$ to $41.8 \%$ (results not presented here). By increasing the HZSM-5:0.5Pd/FeCoCu ratio, the intermediates products contact time with HZSM-5 is increased, which favors oligomerization and aromatization. Hence, these results suggest that a higher HZSM-5: $0.5 \mathrm{Pd} / \mathrm{FeCoCu}$ ratio is preferred to enhance the production of aromatics compounds. 


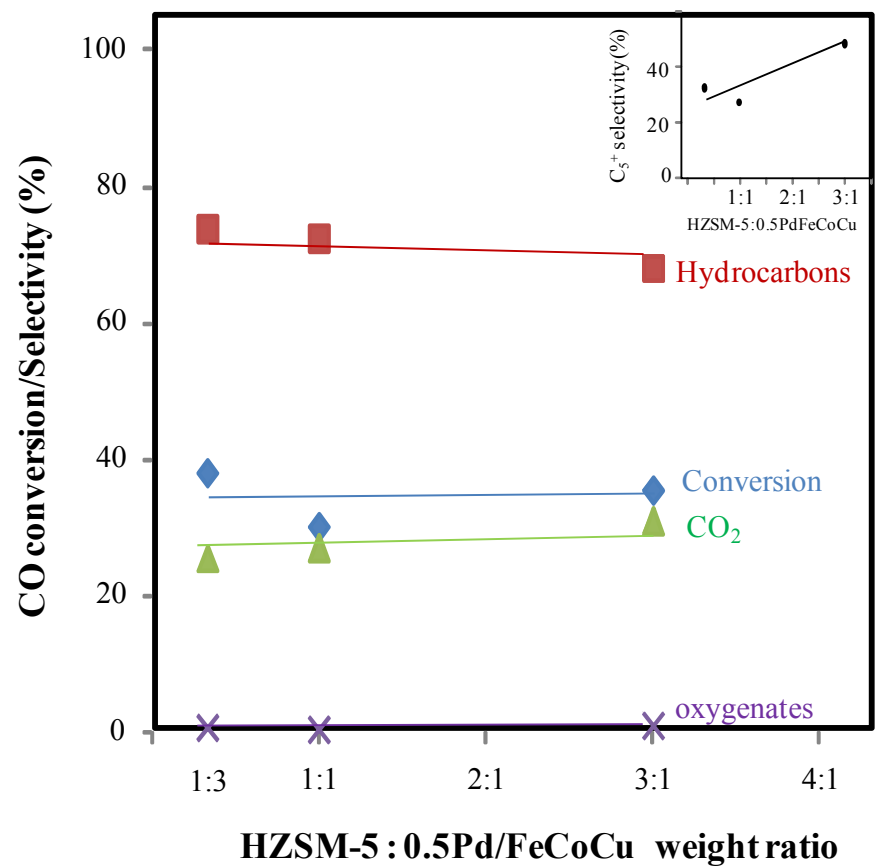

Figure 1.20. CO Conversion and Selectivities as a Function of the HZSM-5:0.5Pd/FeCoCu Ratio for $\mathrm{H}_{2} / \mathrm{CO}=1, \mathrm{~T}=300^{\circ} \mathrm{C}, \mathrm{P}=70$ bars, GHSV $=3000 \mathrm{~h}-1$. Inset: $\mathrm{C} 5+$ selectivity among the hydrocarbons product fraction as a function of the pressure under same reaction conditions.

\subsubsection{One-Step Process vs. Two-Step Process for Conversion of Syngas to Fuels}

In the present study, the conversion of syngas to fuels was conducted in one-step by loading a reactor with a physical mixture of HZSM-5 and $0.5 \mathrm{Pd} / \mathrm{FeCoCu}$. However, as explained in the Chapter 1 , the conversion on syngas to fuels is commercially performed in two separate steps. To simulate a two-step process and compare its efficiency to the present one-step process, we operated a reactor in a down-flow operation with the $0.5 \mathrm{Pd} / \mathrm{FeCoCu}$ catalyst loaded on top of the HZSM- 5 catalyst. $0.5 \mathrm{Pd} / \mathrm{FeCoCu}$ catalyst and HZSM-5 catalyst were separated by $2.5 \mathrm{~cm}$ of quartz wool and a dual thermocouple recording the temperature in the middle of each catalyst bed was used. This two-step process test was conducted under the same reaction conditions as for the one-step process for a direct comparison. Interestingly, the results presented in Table 1.4 show a significant difference in $\mathrm{CO}$ conversion between the two processes. The CO conversion is equal to $\sim 36 \%$ and $\sim 20 \%$, respectively, for the one-step and two-step processes. For the two-step process, a low CO conversion of $\sim 20 \%$ was anticipated. Indeed, as reported in Table 1.3 when the $0.5 \mathrm{Pd} / \mathrm{FeCoCu}$ catalyst was tested in absence of HZSM-5, the CO conversion was equal to $\sim 17 \%$, and $\mathrm{CO}$ conversion is known to occur over the metals sites of the HAS catalyst. HZSM-5 is not expected to be active for the conversion of $\mathrm{CO}$ under the present reaction conditions. $\mathrm{CO}$ conversion is low for the two-step process because of thermodynamic constraints. Syngas conversion is believed to be equilibrium limited, because as shown in Figure 1.17, methanol is the main product and syngas-to-methanol conversion is an equilibrium-limited reaction. For the one-step process, because of the proximity between $0.5 \mathrm{Pd} / \mathrm{FeCoCu}$ and $\mathrm{HZSM}-5$, methanol produced over $0.5 \mathrm{Pd} / \mathrm{FeCoCu}$ catalyst is directly converted into DME over the acid sites of HZSM-5. In that case syngas conversion to methanol is no longer equilibrium limited and higher quantities of $\mathrm{CO}$ are converted. One can also see from Table 1.4 some differences in selectivity between the two processes. 
Table 1.4. Comparison of the Catalytic Performance of the HZSM-5+0.5Pd/FeCoCu Mixture for the One-Step Process and the Two-Step Process $\left(\mathrm{T}=300^{\circ} \mathrm{C}, \mathrm{P}=70\right.$ bars, GHSV $=3000 \mathrm{~h}-1$, $\mathrm{H}_{2} / \mathrm{CO}=1$, HZSM-5: $\left.0.5 \mathrm{Pd} / \mathrm{FeCoCu}=3: 1\right)$

\begin{tabular}{|c|c|c|}
\hline Process & One-Step & Two-Step \\
\hline $\mathrm{CO}$ conversion $(\%)$ & 35.6 & 19.9 \\
\hline \multicolumn{3}{|l|}{ Selectivity (\%): } \\
\hline Hydrocarbons & 68.1 & 80 \\
\hline $\mathrm{CO}_{2}$ & 31 & 15 \\
\hline Oxygenates & 0.9 & 5 \\
\hline \multicolumn{3}{|c|}{ Hydrocarbons product distribution (\%) } \\
\hline $\mathrm{CH}_{4}$ & 26.0 & 35.4 \\
\hline $\mathrm{C}_{2}-\mathrm{C}_{4}$ & 25.5 & 34.2 \\
\hline $\mathrm{C}_{5}^{+}$ & 48.5 & 30.4 \\
\hline Aromatics in $\mathrm{C}_{5}^{+}(\%)$ & 41.8 & 20.5 \\
\hline $\mathrm{C}_{5}^{+}$Yield (\%) & 11.8 & 4.6 \\
\hline
\end{tabular}

The $\mathrm{CO}_{2}$ selectivity is equal to $31 \%$ for the one-step process, and it is twice higher than that of the two-step process. $\mathrm{CO}_{2}$ is produced via WGS reaction over the metals sites of the $0.5 \mathrm{Pd} / \mathrm{FeCoCu}$ catalyst and requires the presence of $\mathrm{CO}$ and $\mathrm{H}_{2} \mathrm{O}$. For the one-step process configuration, the $0.5 \mathrm{Pd} / \mathrm{FeCoCu}$ catalyst is surrounded by higher quantity of $\mathrm{H}_{2} \mathrm{O}$ because of its proximity with $\mathrm{HZSM}-5$. Indeed, $\mathrm{H}_{2} \mathrm{O}$ is partly produced from methanol conversion into DME over the acid sites of HZSM-5. Enhanced WGS occurs for the one-step process configuration likely because increased $\mathrm{H}_{2} \mathrm{O}$ content is available. Although the hydrocarbons selectivity is equal to $80 \%$ for the two-step process and is higher than that of the onestep process (i.e., 68.1\%), detailed analysis of the hydrocarbons product distribution shows that desired $\mathrm{C}_{5}{ }^{+}$production is superior for the one-step process. Another interesting finding is that aromatization is favored for the one-step configuration. The aromatics content among the $\mathrm{C}_{5}{ }^{+}$fraction is equal to $\sim 42 \%$ for the one-step process and equal to only $\sim 21 \%$ for the two-step process. This might be due to the higher conversion for the one-step process. For the one-step process, the oxygenated compounds fraction is negligible and contains mainly acetone and acetic acid, whereas for the two-step process, the oxygenates fraction is five times higher and contains mostly DME. In addition, for the conversion of methanol-to-hydrocarbons, Chang and A. J. Silvestri (1977) observed an increase of the aromatics fractions from $6.6 \mathrm{wt} \%$ to $41.1 \mathrm{wt} \%$ when the methanol + DME conversion increases from $47.5 \%$ to $100 \%$. Finally, the desired $\mathrm{C}_{5}^{+}$yield is equal to $11.8 \%$ for the one-step process and is higher than that for the two-step process with a yield of $4.6 \%$ indicating a higher efficiency of the one-step process. It is worth mentioning that commercial two-step processes produce significantly higher $\mathrm{C}_{5}^{+}$yield than in the present study. However, for commercial two-step processes, syngas-to-methanol and methanol-tohydrocarbons steps are operated under different conditions, thus maximizing yield of intermediates and 
final products. For comparison purposes, it is necessary to operate the one-step process and the two-step process under the same reaction conditions as in the present study. This work clearly shows that a onestep process could be advantageous if $\mathrm{CO}$ conversion would be further increased while minimizing WGS and methanation reactions.

\subsubsection{Collaborative Activities}

Collaborative work with CAS enabled the expertise offered by the Nano and Interfacial Catalysis group, which is led by Professor Xinhe Bao. The Nano and Interfacial Catalysis group is devoted to fundamental research on catalysis pertaining to nanocatalysis and interface chemistry. Particularly beneficial for this research was Dr. Bao's expertise in SiC-supported transition metal catalysis and in surface science understanding of zeolite structures. These capabilities were used for both the SNG production and one-step syngas conversion to fuels areas of research in this project. A student from Prof. Bao's group, Jinjing Li, joined researchers at PNNL in Richland for one year. This work led two jointly authored publications.

Collaboration with the National Energy Technology Laboratory (NETL) was primarily carried out through the interactions with Dr. Charles Taylor. Dr. Taylor has more than 30 years of research and development experience. With a background in SNG production expertise, zeolite chemistry for methanol-to-gasoline type reactions, and with a wide ranging knowledge in catalysis and reaction engineering, he provided expertise that well complemented the expertise of PNNL's research team members.

\subsubsection{Lessons Learned}

The three-way CAS-NETL-PNNL collaboration was found to be a positive experience. The team met on a regular, monthly basis via teleconference. Face-to-face meetings among the Principal Investigators for all three institutions took place on two occasions. The team well complemented each other encompassing expertise across a wide spectrum of fundamental and applied catalysis and reaction engineering. While the team was very strong as, we believe, was the technical delivery, premature funding cuts prevented efforts to perform a techno-economic analysis and obtain further experimental data that would have been useful for informing a go/no-go recommendation for a scale-up demonstration. 


\subsection{Technical Accomplishments}

\subsection{Publications}

Lebarbier VMC, RA Dagle, L Kovarik, KO Albrecht, XS Li, J Li, CE Taylor, X Bao, and Y Wang. 2014. "Sorption-Enhanced Synthetic Natural Gas (SNG) Production from Syngas: A Novel Process Combining CO Methanation, Water-Gas Shift, and $\mathrm{CO}_{2}$ Capture." Applied Catalysis. B: Environmental 144:223-232. Journal 5-Year Impact Factor: 6.0.

Lebarbier VMC, RA Dagle, L Kovarik, KO Albrecht, XS Li, J Li, CE Taylor, X Bao, and Y Wang. "Syngas-to-Hydrocarbons over Higher Alcohols Synthesis Catalysts mixed with HZSM-5." In preparation.

\subsection{Patents}

None

\subsection{Presentations}

Lebarbier VMC, RA Dagle, Y Wang, C Taylor, X Bao, and J Li. 2013. “Syngas Conversion to Hydrocarbon Fuels through Mixed Alcohol Intermediates." Presented by Vanessa Lebarbier at the North American Catalysis Society Meeting, Louisville, Louisville, Kentucky, on June 5, 2013.

Lebarbier VMC, RA Dagle, XS Li, L Li, and Y Wang. 2012. “Sorption-Enhanced Synthetic Natural Gas Production from Syngas: A Novel Process Combining CO Methanation, Water-Gas Shift, and $\mathrm{CO}_{2}$ Capture." Presented by Yong, Wang at the $15^{\text {th }}$ International Congress on Catalysis, Munich, Germany on July 3, 2012.

Dagle RA, Y Wang, and VMC Lebarbier. 2012. "CAS-NETL-PNNL Clean Energy Partnership Area 3: Advanced Syngas Conversion Technologies Focus Area." Presented by RA Dagle at CASNETL-PNNL Clean Energy Partnership Meeting, Pacific Northwest National Laboratory, Richland, Washington, on January 9, 2012.

\subsection{Demonstrated Technical Results}

\subsubsection{Sorption-Enhanced Synthetic Natural Gas Production from Syngas}

SNG production from syngas is under investigation again because of the desire for less dependency from imports and the opportunity for increasing coal utilization and reducing greenhouse gas emissions. CO methanation is highly exothermic and substantial heat is liberated, which can lead to process thermal imbalance and deactivation of the catalyst. As a result, conversion per pass is limited, and substantial syngas recycle is employed in conventional processes. Furthermore, the conversion of syngas to SNG is typically performed at moderate temperatures $\left(275^{\circ} \mathrm{C}\right.$ to $\left.325^{\circ} \mathrm{C}\right)$ to ensure high $\mathrm{CH}_{4}$ yields because this reaction is thermodynamically limited. In this study, the effectiveness of a novel integrated process for SNG production from syngas at high temperature (i.e., $600^{\circ} \mathrm{C}$ ) was investigated. This integrated process consists of combining a $\mathrm{CO}$ methanation nickel-based catalyst with a high temperature $\mathrm{CO}_{2}$ capture 
sorbent in a single reactor. Integration with $\mathrm{CO}_{2}$ separation eliminates the reverse-WGS and the requirement for a separate WGS unit. Easing of thermodynamic constraint offers the opportunity of enhancing yield to $\mathrm{CH}_{4}$ at higher operating temperature $\left(500^{\circ} \mathrm{C}\right.$ to $\left.700^{\circ} \mathrm{C}\right)$, which also favors methanation kinetics and improves the overall process efficiency by exploiting reaction heat at higher temperatures. Furthermore, simultaneous $\mathrm{CO}_{2}$ capture eliminates greenhouse gas emission. In this work, sorptionenhanced $\mathrm{CO}$ methanation was demonstrated using a mixture of a $68 \% \mathrm{CaO} / 32 \% \mathrm{MgAl}_{2} \mathrm{O}_{4}$ sorbent and a $\mathrm{CO}$ methanation catalyst $\left(\mathrm{Ni} / \mathrm{Al}_{2} \mathrm{O}_{3}, \mathrm{Ni} / \mathrm{MgAl}_{2} \mathrm{O}_{4}\right.$, or $\left.\mathrm{Ni} / \mathrm{SiC}\right)$ using a syngas ratio $\left(\mathrm{H}_{2} / \mathrm{CO}\right)$ of 1 , GHSV of $22000 \mathrm{hr}^{-1}$, pressure of $1 \mathrm{bar}$, and a temperature of $600^{\circ} \mathrm{C}$. These conditions resulted in $\sim 90 \%$ yield to methane, which was maintained until the sorbent became saturated with $\mathrm{CO}_{2}$. By contrast, without the use of sorbent, equilibrium yield to methane was only $22 \%$. Cyclic stability of the methanation catalyst and durability of the sorbent also were studied in multiple carbonation-decarbonation cycle studies proving the potential of this integrated process in a practical application.

\subsubsection{Syngas-to-Hydrocarbon Fuels through Higher Alcohol Intermediates}

The synthesis of hydrocarbon fuels directly from syngas was investigated with a catalytic system comprised of HZSM-5 physically mixed with either a methanol synthesis catalyst or a HAS catalyst. The metal sites of the methanol or HAS synthesis catalyst enable the conversion of syngas to alcohols, whereas HZSM-5 offers acid sites necessary for methanol dehydration, and dimethyl ether-tohydrocarbons reactions. Catalytic performance for HZSM-5 when mixed with either a $5 \mathrm{wt} . \%$ $\mathrm{Pd} / \mathrm{ZnO} / \mathrm{Al}_{2} \mathrm{O}_{3}$ methanol synthesis catalyst or a HAS catalyst was evaluated at $300^{\circ} \mathrm{C}, 70$ bars, $\mathrm{GHSV}=700 \mathrm{~h}^{-1}$, and $\mathrm{H}_{2} / \mathrm{CO}=1$ using a HZSM-5: alcohols synthesis catalyst weight ratio of 3:1. Interestingly, the major difference observed between the methanol synthesis catalyst and HAS catalyst mixtures can be found in the durene production. While durene formation is negligible with any of the HAS catalysts evaluated in this study, it represents almost $50 \%$ of the $\mathrm{C}_{5}+$ fraction for the HZSM-5 and $5 \mathrm{wt} . \% \mathrm{Pd} / \mathrm{ZnO} / \mathrm{Al} 2 \mathrm{O} 3$ mixture. This presents an advantage for using HAS catalysts over the methanol synthesis catalyst as durene is an undesirable product. Among all the HAS catalysts evaluated in this study, the $0.5 \mathrm{wt} . \% \mathrm{Pd} / \mathrm{FeCoCu}$ catalyst is the most promising. When mixed with HZSM-5 and operating at $50 \% \mathrm{CO}$ conversion, the selectivity to hydrocarbons is $62 \%$, and the $\mathrm{C} 5+$ fraction represents up to $39 \%$ of the hydrocarbons product. This composite catalytic system was evaluated further under a number of process conditions in an effort to maximize liquid hydrocarbons product yield through balancing of operating parameters. Using a molar syngas $\mathrm{H}_{2}: \mathrm{CO}$ feed ratio of 1 , the effects of temperature $\left(300^{\circ} \mathrm{C}\right.$ to $370^{\circ} \mathrm{C}$ ), pressure (20 to 70 bars), GHSV (700 to $10,000 \mathrm{hr}^{-1}$ ), and varying the HZSM-5:0.5 wt.\% $\mathrm{Pd} / \mathrm{FeCoCu}$ catalyst weight ratio was examined. At $300^{\circ} \mathrm{C}, 70$ bars, $\mathrm{GHSV}=700 \mathrm{~h}^{-1}$ and HZSM-5:0.5 wt. $\% \mathrm{Pd} / \mathrm{FeCoCu}=3: 1(\mathrm{wt})$, an optimal $\mathrm{C} 5+$ yield of $12 \%$ is obtained. For comparison purpose, when the 0.5 wt. $\% \mathrm{Pd} / \mathrm{FeCoCu}$ and $\mathrm{HZSM}-5$ are operated sequentially, this two-step process results in a C5+ yield equal of only $\sim 5 \%$ under comparable conditions. This difference is explained by an improved CO conversion and higher C5+ hydrocarbons fraction when the zeolite and HAS catalysts are physically mixed. The main advantage of the one-step process is that higher syngas conversion can be achieved, as the equilibrium-driven conversion limitations for methanol and dimethyl ether are removed because they are intermediates to the final hydrocarbons product. Unfortunately, high selectivity to liquid product is difficult to achieve because $\mathrm{CO}_{2}, \mathrm{CH}_{4}$, and other light hydrocarbons are formed and suppressing these products in the presence of mixed metal and acid sites proved to be challenging. 


\subsection{Recommended Next Steps, Collaborative Work}

Significant progress was made in the area of sorption-enhanced SNG production. Suitable catalyst and sorbent materials were developed for $\mathrm{CO}$ methanation and $\mathrm{CO}_{2}$-soprtion, respectfully. Proof-of-concept demonstration for the integrated process was accomplished. By exploiting the enhanced kinetics offered at elevated temperature $\left(600^{\circ} \mathrm{C}\right)$, relatively fast throughputs can be achieved (e.g., GHSV=22,000 $\mathrm{hr}^{-1}$ ) with greater than $90 \%$ yield to methane was achieved. By comparison, under these same conditions, without the use of a sorbent, equilibrium yield to methane is only $22 \%$. Thus, $\mathrm{CO}_{2}$ sorption-enhancement was demonstrated, resulting in a process that enabled a high methane yield and simultaneously provided a $\mathrm{CO}_{2}$ stream useful for carbon sequestration. Cyclic stability of the methanation catalyst and durability of the sorbent also were studied in the multiple carbonationdecarbonation cycle studies proving the potential of this integrated process in a practical application. However, long-term catalyst and sorbent stability could be improved with further study. Collaborative investigations of fluid bed operation with $\mathrm{CO}_{2}$ capture and release, rather than fixed bed operation, also needs to be undertaken to minimize significant temperature exotherms. This work would be particularly important for scale-up efforts. Finally, a techno-economic analysis for the process needs to be performed.

Significant efforts also were undertaken in the direct syngas conversion to fuels area. Many oxygenate-producing catalysts were evaluated for combination with zeolite for single-bed conversion. While high $\mathrm{CO}$ conversions could be achieved, selectivity control proved to be difficult. $\mathrm{CO}_{2}, \mathrm{CH}_{4}$, and other light hydrocarbons are formed, and we found that suppressing these products in the presence of mixed metal and acid catalyst sites is challenging. Instead of using mixed oxygenate and ZSM-5 mixtures, we recommend that alternative catalyst systems and process configurations be investigated. Upgrading of products derived from mixed alcohols and/or mixed oxygenates in a separate reactor may still offer advantages compared to conventional methanol-to-gasoline process and Fischer-Tropsch type reactions. For example, zeolite upgrading of higher alcohols minimizes the formation of undesirable durene, in contrast to the more conventional methanol-to-gasoline route. Thus, while one-step conversions currently may be too problematic, two-step processes using novel oxygenate-producing catalysts still hold promise. A techno-economic analysis must also be performed. 


\subsection{References}

Abanades JC and D Alvarez, 2003. "Conversion Limits in the Reaction of $\mathrm{CO}_{2}$ with Lime." Energy \& Fuels 17(2):308-315.

Albrecht KO, KS Wagenbach, JA Satrio, BH Shanks, and TD Wheelock. 2008. "Development of a $\mathrm{CaO}-\mathrm{Based} \mathrm{CO}_{2}$ Sorbent with Improved Cyclic Stability." Industrial \& Engineering Chemistry Research 47(20):7841-7848.

Chang CD and AJ Silvestri. 1977. "The Conversion of Methanol and Other O-Compounds to Hydrocarbons over Zeolite Catalysts.” Journal of Catalysis 47(2): 249-259.

Chang CD, JCW Kuo, WH Lang, SM Jacob, JJ Wise, and AJ Silvestri. 1978. "Process Studies on the Conversion of Methanol to Gasoline." Industrial \& Engineering Chemistry Process Design and Development 17(3):255-260.

Christensen KO, D Chen, RL Deng, and A Holmen. 2006. "Effect of Supports and Ni Crystal Size on Carbon Formation and Sintering during Steam Methane Reforming." Applied Catalysis A: General 314(1):9-22.

Dagle RA, A Platon, DR Palo, AK Datye, JM Vohs, and Y Wang. 2008. "PdZnAl Catalysts for the Reactions of Water-Gas-Shift, Methanol Steam Reforming, and Reverse-Water-Gas-Shift." Applied Catalysis A: General 342(1-2): 63-68.

Fujimura T and S-I Tanaka. 1999. "In-Situ High Temperature X-Ray Diffraction Study of Ni/SiC Interface Reactions.” Journal of Material Science 34(2):235-239.

Gerber MA, JF White, and DJ Stevens. 2007. Mixed Alcohols Synthesis Catalyst Screening. Progress Report. PNNL-16763; Pacific Northwest National Laboratory: Richland, Washington.

Hu J, Y Wang, C Cao, DC Elliott, DJ Stevens, and JF White. 2007. "Conversion of Biomass-Derived Syngas to Alcohols and C2 Oxygenates using Supported Rh Catalysts in a Microchannel Reactor." Catalysis Today 120(1):90-95.

Hughes RW, D Lu, EJ Anthony, and Y Wu. 2004. "Improved Long-Term Conversion of LimestoneDerived Sorbents for In Situ Capture of $\mathrm{CO}_{2}$ in a Fluidized Bed Combustor." Industrial \& Engineering Chemistry Research 43(18):5529-5539.

Imamura $\mathrm{H}$ and WE Wallace. 1979. "Methanation by Catalysts Formed from Intermetallic Compounds." The Journal of Physical Chemistry 83(15):2009-2012.

Jeong H, KI Kim, D Kim, and IK Song. 2006. "Effect of Promoters in Methane Reforming with Carbon Dioxide to Synthesis Gas over Ni/HY Catalysts." Journal of Molecular Catalysis A: Chemical 246(1-2):43-48.

Keil FJ. 1999. "Methanol-to-Hydrocarbons: Process Technology." Microporous and Mesoporous Materials 29(1-2):49-66. 
Kim J-H, DJ Suh, T-J Park, and K-L Kim. 2000. "Effect of Metal Particle Size on Coking during $\mathrm{CO}_{2}$ Reforming of $\mathrm{CH}_{4}$ Over Ni-Alumina Aerogel Catalysts." Applied Catalysis A: General 197(2):191-200.

Kowalczyk Z, K Stolecki, W Rarog-Pilecka, E Miskiewicz, E Wilczkowska, and Z Karpinski. 2008. "Supported Ruthenium Catalysts for Selective Methanation of Carbon Oxide at Very Low $\mathrm{CO} x / \mathrm{H}_{2}$ Ratios." Applied Catalysis A: General 342(1-2):35-39.

Lebarbier VM, RA Dagle, L Kovarik, JA Lizarazo-Adarme, DL King, and DR Palo 2012. "Synthesis of Methanol and Dimethyl Ether from Syngas over $\mathrm{Pd} / \mathrm{ZnO} / \mathrm{Al}_{2} \mathrm{O}_{3}$ Catalysts." Catalysis Science \& Technology 2(10): 2116-2127.

Leroi P, B Madani, C Pham-Huu, M-J Ledoux, S Savin-Poncet, and J.L. Bousquet. 2004. "Ni/SiC: A Stable and Active Catalyst for Catalytic Partial Oxidation of Methane." Catalysis Today 91-92:53-58.

Li L, DL King, Z Nie, XS Li, and C Howard. 2010. " $\mathrm{MgAl}_{2} \mathrm{O}_{4}$ Spinel-Stabilized Calcium Oxide Absorbents with Improved Durability for High-Temperature $\mathrm{CO}_{2}$ Capture." Energy \& Fuels 24(6):36983703.

Manovic V and EJ Anthony. 2007. "Steam Reactivation of Spent CaO-Based Sorbent for Multiple $\mathrm{CO}_{2}$ Capture Cycles.” Environmental Science \& Technology 41(4):1420-1425.

Mokrani T and M Scurrell. 2009. "Gas Conversion to Liquid Fuels and Chemicals: The Methanol Route Catalysis and Processes Development.” Catalysis Reviews 51(1): 1-145.

Rostrup-Nielsen JR. 1975. Steam Reforming Catalysts. Danish Technical Press, Copenhagen, Denmark.

Rostrup-Nielsen JR, K Pedersen, and J Sehested. 2007. "High Temperature Methanation: Sintering and Structure Sensitivity." Applied Catalysis A: General 330:134-138.

Shimizu T, T Hirama, H Hosoda, K Kitano, M Inagaki, and K Tejima. 1999. "A Twin Fluid-Bed Reactor for Removal of $\mathrm{CO}_{2}$ from Combustion Processes." Chemical Engineering Research and Design 77(1):62-68.

U.S. Department of Energy (DOE). 2000. Clean Coal Technology. Available online at www.fe.doe.gov.

Yang X, X Zhu, R Hou, L Zhou, and Y Su. 2011. "The Promotion Effects of Pd on Fe-Cu-Co Based Catalyst for Higher Alcohols Synthesis.” Fuel Processing Technology 92(10): 1876-1880.

Yu Y, G-Q Jin, Y-Y Wang, and X-Y Guo. 2011. "Synthetic Natural Gas from CO Hydrogenation Over Silicon Carbide Supported Nickel Catalysts.” Fuel Processing Technology 92(12):2293-2298.

Xin Q, X Shi, P Ying, and X Guo. 1986. "Interaction Between Metal And Support: Effects of Support Acidity On Adspecies Of Co over Ru.” Reaction Kinetics and Catalysis Letters 31(2):279-283.

Zhao A, W Ying, $\mathrm{H}$ Zhang, $\mathrm{H}$ Ma, and D Fang. 2012. "Ni- $\mathrm{Al}_{2} \mathrm{O}_{3}$ Catalysts Prepared by Solution Combustion Method for Syngas Methanation”. Catalysis Communications 17:34-38. 


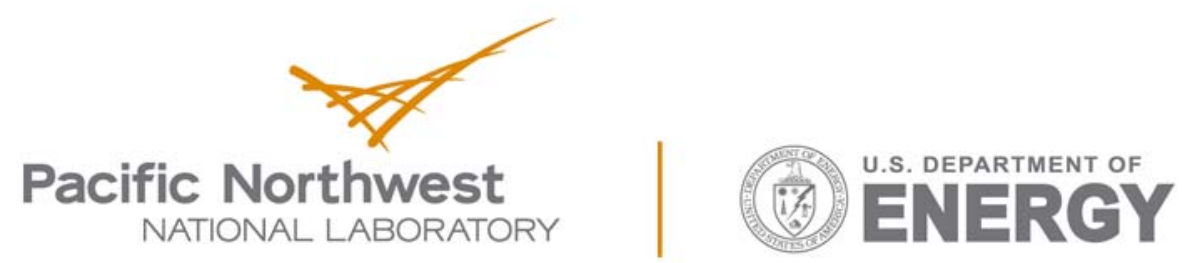

Proudly Operated by Battelle Since 1965

902 Battelle Boulevard

P.O. Box 999

Richland, WA 99352

1-888-375-PNNL (7665)

www.pnnl.gov 